\title{
DRINK LIKE A LAWYER: The Neuroscience of Substance Use AND ITS IMPACT ON COGNITIVE WELLNESS
}

\author{
Debra S. Austin* \\ TABLE OF CONTENTS

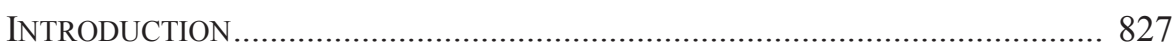

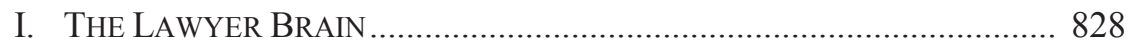 \\ II. MotiVATION AND REWARD IN THE LAWYER BRAIN .......................... 833 \\ III. THE STRESSED LAWYER BRAIN ....................................................... 839 \\ IV. THE SELF-MEDICATED LAWYER BRAIN ........................................... 843

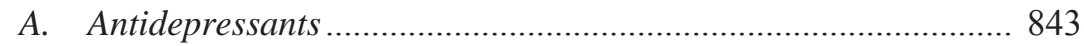

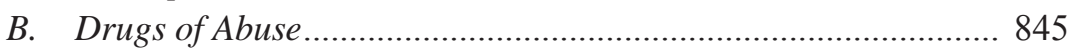

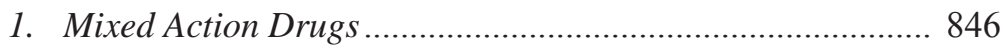

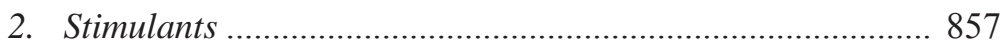

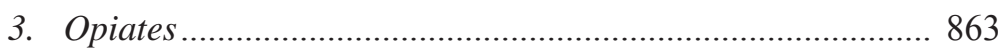

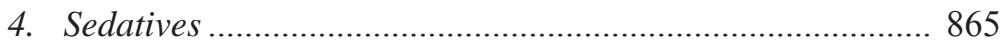

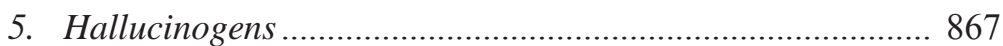 \\ 6. Foods: Sugar, Fat, and Carbohydrates ............................... 867

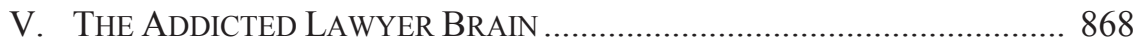

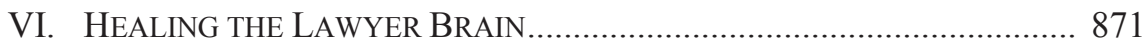 \\ A. Exercise and Brain Health ...................................................... 872 \\ B. Exercise and Stress, Anxiety, and Depression ........................... 876 \\ C. Exercise and Substance Use ................................................... 878 \\ D. Exercise and Culture........................................................... 880

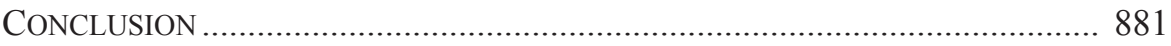

* J.D., Ph.D., Lawyering Process Professor, University of Denver Sturm College of Law. Many thanks to the Hughes-Ruud Research and Development Fund at the University of Denver and to Professor Jean Sternlight, Director of the Saltman Center for Conflict Resolution and Michael and Sonja Saltman Professor of Law at the University of Nevada, Las Vegas Boyd School of Law for their support for this article. 


\section{INTRODUCTION}

Lawyers make powerful contributions to American society within the legal system - by participation in government, and through representation in the news, media, and entertainment businesses. But do they do so while impaired? Lawyers suffer from higher levels of anxiety and depression than the rest of the population, ${ }^{1}$ but most do not enter law school with these mental health issues. ${ }^{2}$ Lawyers rank fourth in professions with the most suicides according to the Centers for Disease Control. ${ }^{3}$ Lawyer suicides are likely linked to stress, anxiety, depression, and/or substance abuse.

Law students, lawyers, and judges are vulnerable to substance abuse. One study concluded that at least 15 percent of lawyers are alcoholics compared to approximately 10 percent in the general population. ${ }^{4}$

Disciplinary actions against attorneys involve substance abuse 50 to 75 percent of the time. ${ }^{5}$ These problems may start in law school where school events may teach students "to drink like a lawyer."

Neuroscience research has shown that both the brain and the genes enjoy the power of plasticity, which means that personal choices and environments shape the development of lawyers throughout their lives. ${ }^{7}$ Major obstacles to legal education reform, enumerated in The Carnegie Report, are also significant sources of chronic stress for law students:

- The competitive classroom climate,

- The competitive atmosphere of most law schools, and

- The grade curve. ${ }^{8}$

\footnotetext{
1 See Nancy Levit \& Douglas O. Linder, The Happy Lawyer: Making a Good Life in THE LaW 6-8 (2010); Douglas Litowitz, The Destruction of Young LaWyers: Beyond One L 16-26 (2006); ANDrew J. McClurg, 1L of A Ride: A Well-Traveled Professor's Roadmap to Success in the First Year of LaW School 315-17 (2009); Rebecca Nerison, Lawyers, Anger, and AnXiety: Dealing with the Stresses of the Legal PROFESSION 15-39 (2010); Lawrence S. Krieger, Institutional Denial About the Dark Side of Law School, and Fresh Empirical Guidance for Constructively Breaking the Silence, $52 \mathrm{~J}$. Legal Educ. 112, 113-15 (2002); Corie Rosen, The Method and the Message, 12 NEV. L.J. 160, 161 n.8 (2011).

2 LitowiTz, supra note 1, at 21; Krieger, supra note 1, at 114.

3 Rosa Flores \& Rose Marie Arce, Why Are Lawyers Killing Themselves?, CNN (Jan. 20, 2014, 2:42 PM), http://www.cnn.com/2014/01/19/us/lawyer-suicides/index.html; see also Patrick Krill, Why Lawyers Are Prone to Suicide, CNN (Jan. 21, 2014, 10:15 AM), http://www.cnn.com/2014/01/20/opinion/krill-lawyers-suicide/index.html.

4 Patrick J. Schiltz, On Being a Happy, Healthy, and Ethical Member of an Unhappy, Unhealthy, and Unethical Profession, 52 VAND. L. REV. 871, 876-77 (1999).

5 Betty Reddy \& Ruth Woodruff, Helping the Alcoholic Colleague, 3 Prof. LAW, May 1992, at 1, 4.

${ }^{6}$ MCCluRG, supra note 1 , at 321.

7 Norman Doidge, The Brain That Changes Itself 240 (2007); Scott Barry Kaufman, UNGIFTED: INTELLIGENCE REDEFINED 10-11 (2013).

8 William M. Sullivan et al., Educating Lawyers: Preparation for the Profession OF LAW 27-29 (2007) (providing the most recent critique of legal education suggesting reforms based on a three apprenticeship model); see NERISON, supra note 1, at 68.
} 
Stressors continue in law practice and include workload, adversarial environments, and win-lose high stakes outcomes. ${ }^{9}$ A common response to chronic stress is self-medication because drugs of abuse can make a lawyer feel less stressed. ${ }^{10}$

The brain can be divided into three functional areas that evolved from the top of the spine up: the primitive brain, the emotional brain, and the thinking brain. ${ }^{11}$ The emotional and thinking brains have a complex relationship, and both are engaged in the learning process ${ }^{12}$ and in the use of substances. ${ }^{13}$ Information moves through the brain in an electrical-chemical-electrical process via communication nerve cells called neurons (electrical) and neurotransmitters between neurons (chemical). ${ }^{14}$ Substance use impacts both the neurons and the neurotransmitters in the brain. ${ }^{15}$

Legal educators need a better understanding of what aspects or characteristics of legal education contribute to the decline in mental health of law students, lawyers, and judges, and neuroscience developments may provide this insight. Law students, lawyers, judges, and law professors will benefit from the knowledge of how stress and substance use effect the lawyer brain. This article describes the neurobiology of learning; explains the brain's reward system; examines the neural impact of stress; details the transformational conditions of neuroplasticity, neurogenesis, and epigenetics; discusses lawyer addiction; and illustrates how medications such as antidepressants, and substances such as alcohol, nicotine, marijuana, caffeine, cocaine, study drugs, and opiates impact brain function. The article concludes with neuroscience-based recommendations for law students, lawyers, judges, law schools, and law firms to optimize brain health and lawyer wellness.

\section{THE LAWYER BRAIN}

The brain is the key tool of the law student, lawyer, judge, and law professor. There are many forms of intelligence. Daniel Goleman wrote about the power of deploying emotional intelligence ("EQ") to improve personal and professional relationships. ${ }^{16}$ Physical health can be improved using the three pillars

9 LEVIT \& Linder, supra note 1 , at 7.

10 Robert M. Sapolsky, Why ZeBras Don't Get Ulcers 346 (3d ed. 2004).

11 Judith Horstman, The Scientific American: Day in the Life of Your Brain 4-6 (2009) [hereinafter HORSTMAN, DAY IN THE LIFE].

12 Rita Carter et al., The Human Brain Book 159 (2009) [hereinafter Carter et AL., Human Brain]; John Medina, Brain Rules: 12 Principles for Surviving and Thriving AT Work, Home AND SCHOOL 103, 109 (2008).

13 CARTER ET Al., Human Brain, supra note 12, at 128.

14 Joseph LeDoux, Synaptic Self: How Our Brains Become Who We Are 47 (2002).

15 Michael S. SweEney, Brain: The Complete Mind 198-203 (2009).

16 See generally Daniel Goleman, Emotional Intelligence (10th ed. 1995); Daniel Goleman, Social Intelligence: The New Science of Human Relationships (2006). 
of body intelligence ("BQ"): awareness, knowledge, and engagement. ${ }^{17}$ Awareness calls for attending to your body's signals. ${ }^{18}$ Knowledge is the development of health literacy and engagement is commitment to an action plan that evolves over time to help one thrive. ${ }^{19}$

What is good for the lawyer's body is also good for the lawyer's brain. An emerging component of BQ is brain health literacy, the knowledge of how to cultivate cognitive fitness. Brain health literacy or neuro-intelligence ("NQ") is a critical competency for lawyers, judges, law faculty, and law students because lawyering is a cognitive profession. The optimistic phenomenon of plasticity in the lawyer brain and genes demonstrates that personal choices, environments, and cultures shape the development of the lawyer's brain throughout life. NQ can improve the cognitive fitness of individual lawyers and law students, and enhance the cognitive wellness of the lawyering profession.

The lawyer brain is the size of a coconut, ${ }^{20}$ and is the consistency of Jell-O ${ }^{21}$ or tofu. ${ }^{22}$ It weighs only three pounds, ${ }^{23}$ yet it uses 20 percent of the body's oxygen, 25 percent of its calories, and 25 percent of its blood flow. ${ }^{24}$ It developed from the top of the spine upward into three functional areas: the primitive brain, the emotional brain, and the thinking brain. ${ }^{25}$

The primitive brain is located above the spine and governs the basic motor functions of breathing, digestion, and heartbeat. ${ }^{26}$ Major components of the primitive brain include the brain stem and cerebellum. ${ }^{27}$ The emotional brain is wrapped around the primitive brain and is in charge of emotions, hunger, circadian rhythm, sex hormones, and addiction. ${ }^{28}$ The major parts of the emotional brain are the amygdala, hippocampus, thalamus, and hypothalamus, and emotional brain components in the reward system are the ventral tegmental area

17 Jim Gavin \& Margaret Moore, Body Intelligence: A Guide to Self-Attunement, 7 IDEA FITNESS J., Nov. 2010, available at http://www.ideafit.com/fitness-library/body-intelli gence-a-guide-to.

${ }^{18} I d$.

19 Id.

20 Rita Carter, Mapping the Mind 14 (2010) [hereinafter Carter, Mapping the Mind].

21 David M. Eagleman, Incognito: The Secret Lives of the Brain 2 (2011).

22 Daniel G. Amen, Change Your Brain Change Your Body: Use Your Brain to Get and KeEP the Body You Have Always Wanted 18 (2010).

23 Gerald M. Edelman, Wider than the Sky: The Phenomenal Gift of Consciousness 15 (2004).

24 AMEN, supra note 22, at 17.

25 Barry J. Gibb, The Rough Guide to the Brain 6-8 (2d ed. 2012); Judith Horstman, The Scientific American: Brave New Brain 3-4 (2010) [hereinafter Horstman, Brave New Brain]; Horstman, Day in the Life, supra note 11; David Perlmutter \& Alberto Villoldo, Power Up Your Brain: The Neuroscience of Enlightenment 16-21 (2011).

${ }^{26}$ GiBB, supra note 25, at 37; Horstman, Brave New Brain, supra note 25, at 3.

27 GiBB, supra note 25, at 36-37.

28 Carter et al., Human Brain, supra note 12, at 53; GibB, supra note 25, at 38-39; Horstman, Brave New Brain, supra note 25 , at 4; Horstman, Day in the Life, supra note 11 , at 4 . 
("VTA"), nucleus accumbens ("NAC"), and ventral pallidum (part of the globus pallidus). ${ }^{29}$ The thinking brain is the walnut-shaped top section ${ }^{30}$ comprised of two hemispheres and four lobes. ${ }^{31}$ The frontal lobe is devoted to reasoning, planning, and language; the occipital lobe is in charge of vision; the temporal lobe controls hearing; and the parietal lobe mediates movement, taste, temperature, and touch. ${ }^{32}$ The thinking brain is responsible for executive function, reasoning, and higher-order thinking. ${ }^{33}$

The primitive, emotional, and thinking sections of the lawyer brain are comprised of two types of brain cells: neurons, which are in charge of communication; and glial cells, which insulate neurons and support their information transport function. ${ }^{34}$ Neurons are shaped like trees with branches at the top called dendrites, a cell body with a nucleus, and a trunk called an axon. ${ }^{35} \mathrm{In}$ formation flows one direction through neurons, from the dendrites at the top of the tree-like structure to the roots of the axon, called the axon terminal. ${ }^{36}$ Dendrites are the input channels of the neuron, and axon terminals are the output channels. ${ }^{37}$

The communication site where the information output axons meet the input dendrites is called the synapse. ${ }^{38}$ Information moves through the neuron as an electrical impulse. ${ }^{39}$ Some neurons move information with purely electrical pathways, ${ }^{40}$ but most neurons transport information across the synapse via chemicals called neurotransmitters. ${ }^{41}$ Information travels as an electrical impulse within the neuron and by chemical neurotransmitter between neurons. ${ }^{42}$ Each brain cell connects with up to 10,000 neighboring cells. ${ }^{43}$

Chemical synaptic transmission is how information flows from neuron to neuron throughout the lawyer brain. ${ }^{44}$ Neurotransmitters leave the axon termi-

29 CARter et AL., Human Brain, supra note 12, at 53-54, 64-65, 128; Horstman, Day IN THE LifE, supra note 11, at 4-5; NEIL V. WATSON \& S. MARC BREEDLOVE, The Mind's MACHINE: Foundations OF BRAIN AND BEHAVIOR 39 (2012).

30 CARTER, MAPping THE Mind, supra note 20.

31 SWEENEY, supra note 15 , at 20-21.

32 CARTer et Al., Human Brain, supra note 12, at 66; CARTer, Mapping The Mind, supra note 20; GIBB, supra note 25, at 40; HorSTMAN, DAY IN THE LiFE, supra note 11, at 6.

33 Perlmutter \& Villoldo, supra note 25, at 19-20.

34 CARTER ET AL., HumAn Brain, supra note 12, at 69; SWEENEY, supra note 15, at 10-11.

35 CARTer et Al., Human Brain, supra note 12, at 69; Sweeney, supra note 15, at 10-11.

${ }^{36}$ GiBB, supra note 25, at 33-35.

37 LeDouX, supra note 14, at 40-41.

38 CARTER ET AL., HumAn BrAin, supra note 12, at 69; LeDoux, supra note 14, at 40-42.

39 GIBB, supra note 25, at 34; SwEENEY, supra note 15, at 14.

${ }^{40}$ Steven A. Siegelbaum \& Eric R. Kandel, Overview of Synaptic Transmission, in Principles of NeURAL Science 177, 178 (5th ed. 2013).

${ }^{41}$ Carter et Al., Human Brain, supra note 12, at 73; Horstman, DAy IN THe Life, supra note 11 , at 6 .

${ }^{42}$ LEDOUX, supra note 14.

43 CARTER, MAPPING THE Mind, supra note 20, at 16.

44 Siegelbaum \& Kandel, supra note 40, at 177. 
nal of the first neuron, move across the tiny synaptic gap, and interact with the dendrite of the next neuron. ${ }^{45}$ A neurotransmitter can either excite or inhibit activity in the receiving neuron. ${ }^{46}$ The brain's major excitatory neurotransmitter is glutamate, ${ }^{47}$ which aids learning and memory by strengthening neural networks. ${ }^{48}$ The main inhibitory neurotransmitter is gamma-aminobutyric acid ("GABA"), ${ }^{49}$ which suppresses messages from your brain to your muscles during sleep to help you to remain still, ${ }^{50}$ and slows the brain by decreasing the electrical impulses between neurons. ${ }^{51}$ In addition to action initiated by neurotransmitters, the synapse is the location where psychoactive drugs and toxins create their impact. ${ }^{52}$

The lawyer brain continuously deploys critical neurotransmitters in chemical synaptic transmissions. ${ }^{53}$ Table 1 provides a snapshot of the major neurotransmitters and their functions. ${ }^{54}$

Three key principles of lawyer brain function are neuroplasticity, neurogenesis, and epigenetics. The brain is a "self-assembled system, wiring up its own synaptic connections." ${ }^{, 55}$ Neuroplasticity is the brain's ability to reshape its neural circuits in response to new experiences. ${ }^{56}$ It can be harmed by illnesses and poor treatment, healed by healthful conditions, and amplified by stimulating environments. ${ }^{57}$ The brain evolves and adapts when exposed to new learning and skills, redesigning the hundreds of millions of connections between neurons. ${ }^{58}$ The neural network is known as the connectome ${ }^{59}$ and each lawyer's system of neural pathways is unique. ${ }^{60}$

45 CARTer ET AL., Human Brain, supra note 12, at 73.

46 Id.; CARTER, MAPPING THE Mind, supra note 20, at 16.

47 Carter, Mapping the Mind, supra note 20, at 29; Steven A. Siegelbaum et al., Synaptic Integration in the Central Nervous System, in PRINCIPLES OF NEURAL SCIENCE, supra note 40 , at $210,213$.

48 SAPOLSKY, supra note 10, at 209-10.

49 James H. Schwartz \& Jonathan A. Javitch, Neurotransmitters, in PRINCIPLES OF NEURAL SCIENCE, supra note 40, at 289, 294.

${ }^{50}$ HORSTMAN, DAY IN THE LiFE, supra note 11, at 165.

51 CARTer et AL., Human Brain, supra note 12, at 125; GiBB, supra note 25, at 155.

52 WATSON \& BREedLOVE, supra note 29, at 94-97.

53 Mark F. Bear et Al., NeURoscience: Exploring the Brain 122 (4th ed. 2015).

54 William J. Broad, The Science of Yoga: The Risks and the Rewards 99-100 (2012); Carter et Al., Human Brain, supra note 12, at 105, 223, 231; CARTer, Mapping the Mind, supra note 20, at 29; Horstman, DAY IN THE LiFe, supra note 11, at 8, 34; DAlE Purves et Al., Principles of Cognitive Neuroscience 389 (2012); John J. Ratey with Eric Hagerman, Spark: The Revolutionary New Science of Exercise and the Brain 37, 64, 117, 121 (2008); SwEENEY, supra note 15, at 15, 213, 221; Christof Koch, The Neuroscience of Consciousness, in FundAMENTAL NEUROSCIENCE 1090, 1095 (2013).

55 Sebastian Seung \& Rafael Yuste, Appendix E: Neural Networks, in Principles of NEURAL SCIENCE, supra note 40, at 1581, 1591.

56 CARTER ET Al., Human Brain, supra note 12, at 193; SweEnEy, supra note 15, at 17.

57 CARTER ET Al., Human Brain, supra note 12, at 193; SweEney, supra note 15, at 13.

${ }^{58}$ DoIDGE, supra note 7, at 45-47. 
TABLE 1: MAJOR NEUROTRANSMITTERS AND THEIR FUnCTIONS

\begin{tabular}{|c|c|c|}
\hline Neurotransmitter & $\begin{array}{l}\text { Post-Synaptic } \\
\text { Effect }\end{array}$ & Function \\
\hline Acetylcholine & $\begin{array}{l}\text { Mostly } \\
\text { Excitatory }\end{array}$ & $\begin{array}{l}\text { Attention, wakefulness, learning, and } \\
\text { memory. Alzheimer's Disease is linked } \\
\text { to low levels of acetylcholine. }\end{array}$ \\
\hline Dopamine & $\begin{array}{l}\text { Excitatory and } \\
\text { Inhibitory }\end{array}$ & $\begin{array}{l}\text { Reward experiences, focuses attention, } \\
\text { motivation, and meaning. }\end{array}$ \\
\hline Endorphins & Inhibitory & $\begin{array}{l}\text { Block pain by docking in opiate recep- } \\
\text { tors. Levels are elevated by exercise. }\end{array}$ \\
\hline $\begin{array}{l}\text { Gamma-aminobutyric } \\
\text { Acid ("GABA") }\end{array}$ & Inhibitory & $\begin{array}{l}\text { Quiets neurons, promotes calm, and } \\
\text { reduces anxiety. GABA is increased by } \\
\text { yoga. Depression is linked to low lev- } \\
\text { els of GABA. }\end{array}$ \\
\hline Glutamate & Excitatory & $\begin{array}{l}\text { Learning, memory, and increase of } \\
\text { synaptic strength. }\end{array}$ \\
\hline Norepinephrine & $\begin{array}{l}\text { Mostly } \\
\text { Excitatory }\end{array}$ & $\begin{array}{l}\text { Regulates moods, blood pressure, } \\
\text { heartbeat, and arouses attention. }\end{array}$ \\
\hline Oxytocin & Inhibitory & $\begin{array}{l}\text { Released during intercourse and preg- } \\
\text { nancy and promotes social bonds and } \\
\text { trust. }\end{array}$ \\
\hline Serotonin & Inhibitory & $\begin{array}{l}\text { Regulates mood, emotion, appetite, and } \\
\text { sleep. Low serotonin produces irritabil- } \\
\text { ity from hunger. Many antidepressants } \\
\text { work by addressing low levels of sero- } \\
\text { tonin. }\end{array}$ \\
\hline
\end{tabular}

The lawyer brain evolves continuously from birth to death. Neurogenesis is the birth of new brain cells in the hippocampus and olfactory bulbs, ${ }^{61}$ structures in the emotional brain. ${ }^{62}$ Until 1998 , scientists believed that the human brain could not grow new brain cells. ${ }^{63}$ Research has shown that neurogenesis can be stimulated by exercise, learning, and antidepressants, ${ }^{64}$ but it can also be suppressed by stress. $^{65}$

59 Sebastian Seung, Connectome: How the Brain's Wiring Makes Us Who We Are, at xiii (2012); Steven A. Siegelbaum \& Eric R. Kandel, Prefrontal Cortex, Hippocampus, and the Biology of Explicit Memory Storage in PRINCIPLES OF NEURAL SCIENCE, supra note 40, at 1524.

60 MedinA, supra note 12, at 66.

${ }^{61}$ Horstman, Brave New Brain, supra note 25, at 8, 10.

${ }^{62}$ Carter et Al., Human Brain, supra note 12, at 64.

63 SweEneY, supra note 15, at 293-94.

${ }^{64}$ Id. at 294.

65 SAPOLSKY, supra note 10, at 217-18. 
At birth, a lawyer's genome is inherited deoxyribonucleic acid ("DNA"). ${ }^{66}$ Epigenetics is the study of how gene regulation is impacted by environments. ${ }^{67}$ Environmental influences change the way genes are expressed (switched on or off ${ }^{68}$ via proteins called the epigenome. ${ }^{69}$ Epigenetics clarifies the impact of nurture on nature because the DNA template lawyers are born with is changed by a transcription function where environments, actions, thoughts, and feelings impact gene expression. ${ }^{70}$ The interaction of genetic makeup and personal experience changes the lawyer brain. ${ }^{71}$

Neuroplasticity, neurogenesis, and epigenetics reveal the brain's capacity to change and heal throughout the life of the lawyer. Armed with the power of NQ, law students, lawyers, law professors, and judges can make decisions that improve cognitive function. Law schools, law firms, and court systems can enhance their cultures to make cognitive wellness a priority.

\section{Motivation AND REWARD IN THE LAWYER BRAIN}

For lawyers, cognition involves a complex interaction between the emotional brain and the thinking brain. ${ }^{72}$ Learning requires the acquisition of new information and the storage of that information in memory. ${ }^{73}$ There are three stages of developing memories for later use: encoding, consolidation, and retrieval. ${ }^{74}$ Information enters the thinking brain, is encoded by the senses, ${ }^{75}$ and moves through the emotional brain in two processes. ${ }^{76}$ The "quick and dirty" route speeds information through the emotional brain's panic button, the amygdala, to assess it for life-threatening potential. ${ }^{77}$ The amygdala aids rapid decision-making where survival is at risk and it is part of memory-storage for emotionally-charged experiences. ${ }^{78}$ The slower analytical route moves information

${ }^{66}$ Horstman, Brave New Brain, supra note 25, at 13.

67 John J. Ratey \& Richard Manning, Go Wild: Free Your Body and Mind From the AfFlictions of Civilization 235 (2014).

68 Doidge, supra note 7, at 220; Cornelia I. Bargmann \& T. Conrad Gilliam, Genes and Behavior, in PrINCIPLES OF NEURAL SCIENCE, supra note 40, at 42.

${ }^{69}$ Doidge, supra note 7, at 220; Horstman, Brave New Brain, supra note 25, at 13.

70 DoIDGe, supra note 7, at 220-21; HorSTMAN, BRAVE NEW BrAin, supra note 25, at 8; Bargmann \& Gilliam, supra note 68 , at 41.

71 Bargmann \& Gilliam, supra note 68, at 63.

72 Carter et Al., Human Brain, supra note 12, at 154-57; SweEney, supra note 15, at $240-43$.

73 SweENEY, supra note 15 , at 236.

${ }^{74} I d$. at 239-40, 246.

75 Id. at 248.

76 CARTER, MAPPING THE Mind, supra note 20, at 83.

77 Carter et al., Human Brain, supra note 12, at 125; Susan Greenfield, The Private Life of the Brain: Emotions, Consciousness, and the SeCret of the Self 18 (2000).

78 CARter et Al., Human Brain, supra note 12, at 158-59; SweEney, supra note 15, at 242. 
through the memory-processing hippocampus in the emotional brain to access prior knowledge and support thoughtful decision-making. ${ }^{79}$

New information is processed by the emotional and thinking brains before it becomes fully consolidated in long-term memory. ${ }^{80}$ Consolidation requires a neural communication loop from senses in the thinking brain, to the hippocampus, and back again. ${ }^{81}$ Memory consolidation takes up to two years, mostly while lawyers sleep, and thus information is recalled from this emotionalthinking brain neural loop for an extended period of time. ${ }^{82}$ Eventually, fully consolidated memories reside in the thinking brain of the lawyer in the knowledge network connectome. ${ }^{83}$ The process of encoding, consolidation, and retrieval conducted by the emotional and thinking brains is a learning system.

Eric R. Kandel, who won the Nobel Prize for research on the molecular foundations of learning, ${ }^{84}$ discovered that learning takes place through the synaptic interaction of neurotransmitters and receptors. ${ }^{85}$ Synaptic transmission, where an electrical spike travels through a neuron and triggers the release of neurotransmitters that disperse across the synaptic cleft and bind to receptors, is strengthened with use. ${ }^{86}$ When neurons fire repeatedly, the process is called long-term potentiation ("LTP") ${ }^{87}$ LTP is the basis of synaptic plasticity, ${ }^{88}$ and Canadian psychologist Donald Hebb described LTP as the process where "[c]ells that fire together wire together." ${ }^{\text {" }} 9$ The lawyer brain is continuously rewired by experiences, thoughts, and feelings. ${ }^{90}$

Motivation and reward also involve a complicated interplay between the lawyer's emotional and thinking brain. ${ }^{91}$ The amygdala helps determine whether an experience is pleasurable and to be repeated, or unpleasant and avoided. ${ }^{92}$

79 CARter et Al., Human Brain, supra note 12, at 125; CARTer, MapPing the Mind, supra note 20 , at $83-84$.

80 CARTer et Al., Human Brain, supra note 12; CARTER, MAPPIng THE Mind, supra note 20 , at 164 .

${ }^{81}$ Carter et Al., Human Brain, supra note 12; SweEney, supra note 15, at 252.

82 CARTER ET Al., Human Brain, supra note 12, at 159.

83 Id.; MedinA, supra note 12, at 140-41; SEUNG, supra note 59, at 79; Daniel L. Schacter \& Anthony D. Wagner, Learning and Memory, in PrINCIPLES OF NEURAL SCIENCE, supra note 40 , at $1441,1448$.

84 SWEENEY, supra note 15 , at 236.

85 SWEENEY, supra note 15 , at 236.

86 David J. Linden, The Compass of Pleasure 54-55 (2011).

87 CARTER, MAPPING THE Mind, supra note 20, at 160; Linden, supra note 86, at 55; SWEENEY, supra note 15, at 248.

${ }^{88}$ Joseph R. Manns \& Elizabeth A. Buffalo, Learning and Memory: Brain Systems, in Fundamental NEUROSCIENCE, supra note 54, at 1029, 1029-30.

89 LeDouX, supra note 14, at 79.

90 RATEY, supra note 54, at 36.

91 CARTER ET Al., Human Brain, supra note 12, at 128.

92 Horstman, DAY IN THE LiFe, supra note 11, at 77. 
The hippocampus begins to store the memories associated with the experience, including where it took place and who was present. ${ }^{93}$

The neurotransmitter most associated with reward seeking is dopamine, which is released by the ventral tegmental area ("VTA") in the emotional brain. ${ }^{94}$ Long neurons in the VTA extend their axon trunks to several target areas in the emotional brain: the nucleus accumbens (abbreviated as "NAC", this structure relates to pleasure and reward); the amygdala and anterior cingulate cortex (emotional centers); the dorsal striatum (habit learning); and the hippocampus (memory processing). ${ }^{95}$ The VTA axons also extend to the prefrontal cortex (reasoning, judgment, and planning) in the thinking brain. ${ }^{96}$ The specialized VTA axons deliver dopamine to these emotional and thinking brain targets. $^{97}$

The VTA neurons are excited into dopamine release by neurons in the medial forebrain bundle ("MFB"), made up of the amygdala, NAC, septum, and prefrontal cortex. ${ }^{98}$ The MFB axons dispatch the neurotransmitter glutamate to activate dopamine release in the VTA. ${ }^{99}$ The evolutionary purpose of the mesolimbic dopamine system (hereinafter dopamine system) in the lawyer brain is to drive eating and procreation to ensure survival. ${ }^{100}$

Synaptic transmission in the lawyer brain has four stages: 1) synthesis and storage of the transmitter in the pre-synaptic neuron; 2) transmitter release; 3) interaction of the transmitter with the receptors on the post-synaptic neuron; and 4) removal of the transmitter from the synaptic cleft. ${ }^{101}$ VTA neurons specialize in synthesis, storage, and release of dopamine. ${ }^{102}$ After release, transmitters bind to receptors and initiate changes in the post-synaptic cell. ${ }^{103}$ Neurotransmitters are inactivated when they are removed from the synaptic cleft by reuptake back into the pre-synaptic neuron, or they are broken down by enzymes. $^{104}$

93 Id.

94 DoIDGe, supra note 7, at 106; see Linden, supra note 86, at 3-4. Dr. Arvid Carlsson of the University of Gothenburg in Sweden discovered dopamine as a neurotransmitter in 1957. He received the 2000 Nobel Prize for Medicine for his discovery. Vikram K. Yeragani et al., Arvid Carlsson, and the Story of Dopamine, 52 InDIAN J. PSYCHIATRY 87-88 (2010), available at http://www.ncbi.nlm.nih.gov/pmc/articles/PMC2824994/.

95 GiBB, supra note 25, at 176-77; HorSTMAN, DAY IN THE LiFe, supra note 11, at 77; LINDEN, supra note 86, at 16-18; SWEENEY, supra note 15, at 177.

96 GIBB, supra note 25, at 176-77; LINDEN, supra note 86, at 16-18.

97 Horstman, DAY IN THE LiFe, supra note 11, at 77.

98 Id.; LINDEN, supra note 86, at 18.

99 LiNDEN, supra note 86 , at 18.

100 GIBB, supra note 25, at 176.

101 Schwartz \& Javitz, supra note 49, at 289.

102 LINDEN, supra note 86, at 15-16.

103 Jerrold S. Meyer \& Linda F. Quenzer, Psychopharmacology: Drugs, the Brain, AND BEHAVIOR 27 (2d ed. 2013).

104 Id. at 85-86. 
In order to complete communication between neurons, transmitters must bind to receptors on the dendrites of the target neurons. ${ }^{105}$ Receptors have the ability to recognize specific molecule shapes of transmitters, or of drugs that mimic transmitters. ${ }^{106}$ Transmitters or drugs that have the best chemical fit attach to the receptors and activate them. ${ }^{107}$ These activating transmitters or drugs are called agonists. ${ }^{108}$ Drugs that fit into and bind to receptors, but that do not activate them, are called receptor antagonists. ${ }^{109}$ Antagonists block the receptor and prevent activation. ${ }^{110}$

Scientists used to describe balance in the body systems as homeostasis. ${ }^{111}$ The newer equilibrium model, allostasis, acknowledges that the body is comprised of numerous interacting systems including the nervous, endocrine, circulation, immune, and digestive systems. ${ }^{112}$ The brain coordinates body-wide changes in these systems to maintain allostasis. ${ }^{113}$ This allows energy transfer between systems, to deal with changing conditions and to build capacity for future challenges. ${ }^{114}$ The systems can also recalibrate in order to adjust to changes within them. ${ }^{115}$ Receptors respond to an absence of agonists (activator transmitters) by increasing their numbers and this receptor growth process is called up-regulation. ${ }^{116}$ When receptors are chronically activated by the presence of too much transmitter, they respond by reducing their numbers, known as down-regulation. ${ }^{117}$

One example of a recalibration is when poor diet causes persistent elevation of blood glucose and the body responds with increased insulin production. ${ }^{118}$ When the endocrine system learns to expect high insulin levels, it reduces the number of insulin receptors. ${ }^{119}$ The down-regulation of insulin receptors causes insulin resistance. ${ }^{120}$

High levels of dopamine in the lawyer brain cause a recalibrating downregulation of the dopamine system. ${ }^{121}$ Down-regulation of dopamine receptors

\footnotetext{
105 LiNDEN, supra note 86 , at 16-17.

106 MEYer \& QUENZER, supra note 103, at 27-28.

107 Id.

108 Id. at 28.

${ }^{109} I d$.

$110 \mathrm{Id}$.

111 RATEY \& MANNING, supra note 67, at 233.

112 Id.

113 SAPOLSKY, supra note 10, at 9.

114 RATEY \& MANNING, supra note 67, at 233-36.

$115 I d$. at 235.

116 MEYER \& QUENZER, supra note 103, at 28.

117 Id.

118 RATEY \& MANNING, supra note 67, at 235-36.

$119 I d$. at 236.

${ }^{120} \mathrm{Id}$.

${ }^{121} I d$. at 237.
} 
is caused by repeated use of drugs that artificially activate the dopamine system. ${ }^{122}$

Scientists have learned about the dopamine system from studying the behavior of rodents and their willingness to forgo food, breeding, and their offspring to self-stimulate this system using electrodes or psychoactive drugs. ${ }^{123}$ Extensive parallel discoveries have been made in brain research involving rodents and humans, and thus findings on the rodent dopamine system help to explain lawyer willingness to self-medicate with, and in some cases become addicted to, substances that activate the dopamine system. ${ }^{124}$

Neuroscientist Peter Sterling described the brain's role in allostatic recalibration as a series of sticks (pain) and carrots (pleasure) that motivate adaptation. ${ }^{125}$ Dopamine was thought to be the pleasure carrot that motivates behavior, but motivation, reward seeking, and reinforcement have a much more complex story. ${ }^{126}$

Desire is yearning for a reward you believe will result in pleasure or satisfaction. ${ }^{127}$ Reward seeking has three elements: motivation, learning, and pleasure. ${ }^{128}$ Motivation is the desire to obtain an incentive, and learning is the process that occurs when action leads to acquisition of the incentive. ${ }^{129}$ Pleasure is the subjective feeling when a reward is enjoyed. ${ }^{130}$

Achieving a reward involves both the thinking-emotional brain learning system and the dopamine system (release of dopamine by the VTA in the NAC), ${ }^{131}$ which together forms a motivation control system. ${ }^{132}$ When a lawyer feels a need, such as hunger, it is registered in the VTA, which releases dopamine in the NAC. ${ }^{133}$ The NAC responds by releasing an opioid-like peptide transmitter in the VTA, which forms a circuit. ${ }^{134}$ NAC neurons prompt motor activity in the basal ganglia causing an increase in physical activity. ${ }^{135}$ The dopamine system promotes arousal, effort, and activity to help the lawyer respond

122 MEYer \& QuENZER, supra note 103, at 28.

123 Linden, supra note 86, at 20; Peter B. Shizgal \& Steven E. Hyman, Homeostasis, Motivation, and Addictive States, in PrinciPles of Neural ScIEnCE, supra note 40, at 1095, 1104.

124 LeDouX, supra note 14, at 220; Linden, supra note 86, at 16; MEYER \& QuENZER, supra note 103 , at 248 .

125 RATEY \& MANNING, supra note 67, at 236-37.

126 William A. McKim \& Stephanie D. Hancock, Drugs and Behavior: AN InTROdUCtion to BeHAVIORAL PHARMACOLOGY 115 (7th ed. 2013).

127 CARTER ET AL., Human BRAIN, supra note 12, at 128; PURVES ET AL., supra note 54, at 472.

128 MEYER \& QUENZER, supra note 103, at 250.

129 Id.

${ }^{130} \mathrm{Id}$.

131 MCKIM \& HANCOCK, supra note 126, at 115-19.

${ }^{132} I d$. at 115 .

$133 \mathrm{Id}$.

134 Id.

${ }^{135}$ Id. 
to his hunger. ${ }^{136}$ At the same time, the learning system is receiving information from the senses, which is sorted by the thalamus and directed to the amygdala and hippocampus. ${ }^{137}$ Here, memory and past action are considered in evaluating stimuli for potential in acquiring the incentive. ${ }^{138}$

If the lawyer was a young hungry coyote, the activation of his dopamine system would prompt an increase in motor activity. ${ }^{139}$ Increased activity might result in finding an unsuspecting prairie dog by accident. ${ }^{140}$ When the coyote happens upon the prairie dog, the VTA releases more dopamine in the NAC and the location of the prairie dog field is registered in the thinking-emotional brain (cortex-hippocampus) memory loop. ${ }^{141}$ The prairie dog field acquires incentive salience for the coyote, which means that future hunger-inspired dopamine system activation will prompt a return visit to the prairie dog field. ${ }^{142}$ If the coyote wanders by the field when he is not hungry, the dopamine system will be activated not by hunger, but by the prairie dog field stimulus. ${ }^{143}$

The role of dopamine, once thought to be responsible for the subjective feeling of pleasure, ${ }^{144}$ has been challenged by experiments that manipulate dopamine. ${ }^{145}$ In rodent studies, genetically altered dopamine-deficient mice are able to learn stimulus-reward associations and mice that have prolonged dopamine in the synapses do not learn any faster than normal mice. ${ }^{146}$ Parkinson's patients, who suffer from a lack of dopamine, do not report less pleasure when eating sweet foods; nor does administering dopamine to their NAC increase their feelings of pleasure. ${ }^{147}$ And experienced cocaine users, who were treated with a dopamine-depleting drug prior to cocaine use, reported reduced craving for cocaine, but no reduction in cocaine-induced euphoria. ${ }^{148}$ The role of dopamine appears to be a consequence of associative learning, responsible for motivation, but not sensations of pleasure. ${ }^{149}$

Current research indicates that pleasure in the rodent motivation control system seems to be located in tiny hedonic hotspots in the NAC and the ventral

\footnotetext{
${ }^{136} I d$.

137 Id.

138 Id.

$139 \mathrm{Id}$. at 116.

$140 \mathrm{Id}$.

141 Id. at $116-17$.

$142 I d$. at 117.

143 Id.

144 MEYer \& QuenZER, supra note 103, at 250-51.

145 MCKIM \& HANCOCK, supra note 126, at 117; MEYER \& QUENZER, supra note 103, at 251.

146 MCKIM \& HANCOCK, supra note 126, at 117.

147 Id. at 118 .

148 Meyer \& QuenZer, supra note 103, at 251.

149 MCKIM \& HANCOCK, supra note 126, at 117; MEYER \& QUENZER, supra note 103, at 251.
} 
pallidum. ${ }^{150}$ In rodents, facial responses to sweet (rewarding) flavors can be enhanced by opioids and cannabinoids in these hot spots. ${ }^{151}$ Stimulation of the hotspots is not dependent on dopamine. ${ }^{152}$ Dopamine appears to be critical to motivation and the reinforcing effects of rewards, ${ }^{153}$ while opioid receptors in the ventral pallidum seem to stimulate pleasure in the lawyer brain. ${ }^{154}$ The lawyer brain produces naturally-occurring opioids and endocannabinoids, which would explain the subjective pleasure experience associated with drug use. ${ }^{155}$

\section{THE STRESSED LAWYER BRAIN}

Americans suffer from overwork. Research shows that 37.8 percent of professional men and 14.4 percent of professional women work more than fifty hours a week. ${ }^{156}$ Overwork is a practice that lawyers likely adopt during law school, where success is defined in terms of grades, class rank, and selection to serve on journals. ${ }^{157}$ Lawyers suffer from higher levels of anxiety and depression than the rest of the population, ${ }^{158}$ but most do not enter law school with these mental health issues. ${ }^{159}$ Depression is an emotional state of having too few positive emotions along with too many negative ones, often coupled with feelings of intense grief and guilt. ${ }^{160}$ According to the Centers for Disease Control, lawyers rank fourth in professions with the highest number of suicides. ${ }^{161}$ Lawyer anxiety, depression, and suicide rates are likely linked to overwork and chronic stress. ${ }^{162}$

The six primary emotions recognized by psychologists are fear, anger, sadness, disgust, surprise, and joy. ${ }^{163}$ Emotions are automatic and unconscious physiological responses to stimuli that cause physical changes like blushing,

150 MCKIM \& HANCOCK, supra note 126, at 118; MEYER \& QUENZER, supra note 103, at 251; Kyle S. Smith et al., Ventral Pallidum Roles in Reward and Motivation, 196 BEHAV. BraIN RES. 155, 156-57 (2009).

151 MCKIM \& HANCOCK, supra note 126, at 118-19; MEYER \& QUENZER, supra note 103, at 251.

152 MCKIM \& HANCOCK, supra note 126, at 118.

$153 \mathrm{Id}$. at 119.

154 Smith et al., supra note 150 , at 158.

155 McKim \& Hancock, supra note 126, at 318; Meyer \& QuenZer, supra note 103, at 407.

156 Julian Ford \& Jon Wortmann, Hijacked by Your Brain: How to Free YourselF WHEN STRESS TAKES OVER 18-19 (2013).

157 LEVIT \& LinDER, supra note 1, at 125.

158 See LeVIT \& Linder, supra note 1; Litowitz, supra note 1; MCCLURG, supra note 1; NERISON, supra note 1; Krieger, supra note 1; Rosen, supra note 1.

159 Krieger, supra note 1 , at 114.

160 SAPOLSKY, supra note 10, at 273.

161 Flores \& Arce, supra note 3.

162 LEVIT \& LINDER, supra note 1, at 7.

163 SwEENEY, supra note 15, at 208. 
sweaty palms, and increased heart rate and blood pressure. ${ }^{164}$ Feelings are conscious perceptions of automatic emotional responses. ${ }^{165}$ Stress involves some combination of negative emotions. ${ }^{166}$

The autonomic nervous system works with the lawyer's brain to maintain allostatic balance. ${ }^{167}$ The two divisions of the autonomic system maintain this stability: the sympathetic nervous system ("SNS") and the parasympathetic nervous system ("PNS"). ${ }^{168}$ The SNS is commonly known as the fight-or-flight system and the PNS as the rest-and-digest system. ${ }^{169}$ The fight-or-flight arousal system is the body's accelerator and the rest-and-digest calming system is its brake. $^{170}$

The lawyer fight-or-flight SNS was designed to produce rapid response when escape from predators was a priority. ${ }^{171}$ This system is activated during acute stress, which is short-lived and potentially helpful in dealing with shortterm challenges, such as a court hearing or a $5 \mathrm{~K}$ run. ${ }^{172}$ However, the SNS can be perpetually activated during long-term chronic stress, such as job loss, financial problems, troubled family relationships, or possibly law school. ${ }^{173}$

The fight-or-flight SNS response starts in the lawyer's emotional brain, and is ignited by the brain's "panic button," the amygdala. ${ }^{174}$ The amygdala initiates the quick and dirty route to SNS activation by signaling the thalamus to focus attention and the hypothalamus to release stress hormones. ${ }^{175}$ The two primary stress hormones are adrenaline (also known as epinephrine) and glucocorticoids (the main glucocorticoid is cortisol). ${ }^{176}$ Stress hormones elevate heart

164 CARTER ET AL., Human Brain, supra note 12, at 124; GiBB, supra note 25, at 96; SwEENEY, supra note 15, at 208; Joseph E. LeDoux \& Antonio R. Damasio, Emotions and Feelings, in PrinciPles of NeURAL ScIENCE, supra note 40, at 1079, 1079.

165 LeDoux \& Damasio, supra note 164.

166 See CARTer et AL., Human Brain, supra note 12, at 232; CARTer, Mapping the Mind, supra note 20, at 96-97.

167 Terry L. Powley, Central Control of Autonomic Functions: Organization of the Autonomic Nervous System, in Fundamental Neuroscience, supra note 54, at 729, 729; see John P. Horn \& Larry W. Swanson, The Autonomic Motor System and the Hypothalamus, in PRINCIPLES OF NeURAL SCIENCE, supra note 40, at 1056, 1066-67.

168 PURVES ET AL., supra note 54, at 326.

169 PURVES ET AL., supra note 54, at 326.

170 Linda Graham, Bouncing Back: Rewiring Your Brain for Maximum Resilience AND WELL-BEING 201 (2013).

171 Byron A. Campbell et al., Origins of Orienting and Defensive Responses: An Evolutionary Perspective, in Attention and Orienting: Sensory and Motivational Processes (Peter J. Lang et al. eds., 2011).

172 Perlmutter \& Villoldo, supra note 25, at 59.

173 Perlmutter \& Villoldo, supra note 25, at 59; see Litowitz, supra note 1, at 10, 19.

174 RATEY, supra note 54, at 62.

175 CARTER ET AL., Human Brain, supra note 12, at 125; GreENFIEld, supra note 77, at 18; Rick Hanson, Buddha's Brain: The Practical Neuroscience of Happiness, Love, \& WISDOM 52 (2009).

176 Carter et Al., Human Brain, supra note 12, at 232; Medina, supra note 12, at 174; Perlmutter \& Villoldo, supra note 25, at 60; SweEney, supra note 15, at 40; Andrea C. 
rate, raise blood pressure, mobilize energy, slow digestion, and suppress the immune system. ${ }^{177}$ Fight-or-flight SNS activation is meant to help solve shortterm problems, like the evasive action required to escape harm. ${ }^{178}$ Chronic stress causes long-term elevated levels of glucocorticoids, causing the following serious health problems: a compromised immune system; increased appetite and body fat; decreased muscle mass and bone density; and increased irritability, anger, anxiety, and depression. ${ }^{179}$

Lawyer stress can be described as a physiological response to a stressor: 1) that is measurable by another party, 2) that the lawyer perceives as negative, and 3) that the lawyer feels she has no control over. ${ }^{180}$ The Carnegie Report, the most recent critique of legal education, states that chronic law student stress is caused by the grade curve and competitive learning atmosphere. ${ }^{181}$ Stressors continue in law practice and include tight deadlines, adversarial environments, and win-lose high stakes outcomes. ${ }^{182}$ Bar examiners frequently ask about mental health and addiction issues on bar applications, and three states (Georgia, Minnesota, and North Carolina) suggest that lawyer stress starts in law school. $^{183}$

Damage from chronic stress extends to the lawyer brain. Activation of the fight-or-flight SNS causes circular damage in the emotional brain because cortisol causes the amygdala to produce additional cortisol and the hippocampus,

Gore, Neuroendocrine Systems, in FundAMENTAL NeurosCiEnCE, supra note 54, at 799, 804; Steven E. Hyman \& Jonathan D. Cohen, Disorders of Mood and Anxiety, in PrinciPleS OF NEURAL SCIENCE, supra note 40, at 1402, 1409. The pituitary gland and the hypothalamus in the emotional brain tell the adrenal gland sitting atop the kidneys to release adrenalin and glucocorticoids. CARTer et Al., Human Brain, supra note 12, at 232; Perlmutter \& VILLOLDO, supra note 25, at 60.

177 Perlmutter \& Villoldo, supra note 25, at 60; Gore, supra note 176, at 804; see SAPOLSKY, supra note 10 , at 13.

178 MedinA, supra note 12, at 175.

179 See Sapolsky, supra note 10, at 13; Shawn M. TAlbott, The Cortisol Connection 22 (2007).

${ }^{180}$ MedinA, supra note 12, at 173-74 (Jeansok Kim and David Diamond developed this three-part definition of stress).

181 SULLIVAN ET AL., supra note 8, at 31.

182 LEVIT \& LINDER, supra note 1, at 7.

183 Rebecca S. Mick, Making the Mark-Character and Fitness for Admission to the Bar, GA. B. Admissions 8, https://www.gabaradmissions.org/making-the-mark (last visited Apr. 12, 2015) ("The Board understands that law school and life in general can be stressful and may result in an applicant's seeking counseling or other treatment."); Character and Fitness for Admission to the Bar, MinN. ST. BD. L. EXAMINERS (Oct. 2014), http://www.ble.state.mn.us/resource-center/character-and-fitness-for-admission-to-bar.aspx ("Bar examiners recognize that the stresses of law school and other life factors may result in an applicant suffering from psychological problems."); Character and Fitness Guidelines, N.C. BD. L. EXAMINERS, http://www.ncble.org/character-fitness/ (last visited Apr. 12, 2015) ("Board members recognize that the stresses of law school, as well as other life factors, frequently result in applicants seeking psychiatric or psychological counseling."). 
normally responsible for calming the amygdala, is suppressed. ${ }^{184}$ The amygdala is over-sensitized and the hippocampus is compromised. ${ }^{185}$

Where the SNS stimulates arousal, defense, and escape, the rest-and-digest PNS promotes nourishment, procreation, and the return to allostatic balance after SNS activation. ${ }^{186}$ The PNS slows the heart rate, lowers blood pressure, promotes digestion, and suppresses the release of adrenaline. ${ }^{187}$ Law students and lawyers benefit from learning how to enhance the rest-and-digest PNS.

Many law students and lawyers spend months and years in fight-or-flight SNS overdrive, believing their performance is improved by the adrenalin rush. ${ }^{188}$ This plight may be fueled by caffeine and other substances. ${ }^{189}$ Neuroscientists have proven that cognitive performance is diminished during flightor-flight SNS arousal. ${ }^{190}$ The impact of stress on lawyer brain cognition includes degradation of the following functions: concentration, memory, problem-solving, language processing, and math performance. ${ }^{191}$

The hippocampus, the brain's memory processor, is highly susceptible to stress because it has abundant glucocorticoid receptors. ${ }^{192}$ Glucocorticoids damage and kill cells in the hippocampus and weaken synaptic connections. ${ }^{193}$ Damage to the hippocampus can create a harmful cycle where greater glucocorticoid release produces additional hippocampal atrophy. ${ }^{194}$ Brain scans show hippocampi shrink in size in people who experience post-traumatic stress disorder, major depression, and repeated jet lag, and right hippocampus volume is reduced in young chronic cannabis users. ${ }^{195} \mathrm{~A}$ common response to chronic stress is self-medication because drugs of abuse can make a lawyer feel less stressed. ${ }^{196}$

184 HANSON, supra note 175, at 52-53; RATEY, supra note 54, at 66-67.

185 HANSON, supra note 175, at 57.

186 David G. Amaral \& Peter L. Strick, The Organization of the Central Nervous System, in Principles of Neural SCIENCE, supra note 40, at 337, 353; Horn \& Swanson, supra note 167, at 1066.

187 BROAD, supra note 54, at 90; SwEENEY, supra note 15, at 41; Powley, supra note 167, at 734.

188 Gayatri Devi, a Calm Brain: How to Relax into a Stress-Free, High-Powered LIFE 6 (2012).

189 Id. at $15-16$.

190 HANSON, supra note 175, at 52-60; RATEY, supra note 54, at 67-71; see DeVI, supra note 188 , at $83-86$.

191 MEDINA, supra note 12, at 178.

192 Id. at 177; Gore, supra note 176, at 804.

193 SAndra Aamodt \& SAm Wang, Welcome to Your Brain 86 (2008); Amen, supra note 22, at 248; DoIdGe, supra note 7; Medina, supra note 12, at 179; DAVID A. SousA, How Brain Science Can Make You a Better Lawyer 25 (2009); Gore, supra note 176, at 804.

194 SAPOLSKY, supra note 10 , at 387.

195 MCKIM \& HANCOCK, supra note 126, at 322; SAPOLSKY, supra note 10, at 221.

196 SAPOLSKY, supra note 10. 


\section{The SELF-Medicated LAWYER BRAIN}

The broadest definition of the term drug is "any substance that alters the physiology of the body," which can include food. ${ }^{197}$ Some drugs serve as nutrients, some treat disorders, and some are consumed to produce a high. ${ }^{198}$

Lawyers suffer from anxiety and depression at rates that are higher than the rest of the population. ${ }^{199}$ Some of them turn to antidepressants for relief and others may self-medicate with drugs of abuse or food.

\section{A. Antidepressants}

Antidepressants improve depression in approximately two-thirds of people who try them. ${ }^{200}$ A study of the placebo effect in fifty-one people with major depression found that 52 percent receiving antidepressant medications and 38 percent receiving placebos responded positively to treatment. ${ }^{201}$ Factors that improve the placebo expectancy effect include a good relationship with the doctor, positive expectations of the medicine, and a desire to feel better. ${ }^{202}$ The results suggest that depression can be improved in multiple ways because placebo-takers showed an increase in thinking brain prefrontal cortex activity, while the drug-takers showed decreased activity in the same region. ${ }^{203}$ Because antidepressants reduce anxiety in depressed patients, they are also being prescribed to treat anxiety that is unrelated to depression. ${ }^{204}$

Monoamine transmitters are synthesized from amino acids and include norepinephrine, dopamine, and serotonin. ${ }^{205}$ Scientists believe that depression is linked to low levels of serotonin. ${ }^{206}$ When neurotransmitters are released, the presynaptic neuron keeps the communication signal clean and precise by clearing excess transmitter from the synaptic gap. ${ }^{207}$ Removal and recycling of the transmitter is called reuptake, when the transmitter is returned to the presynaptic neuron via a transporter. ${ }^{208}$ Neurotransmitters can also be degraded and

197 MCKIM \& HANCOCK, supra note 126, at 1.

198 Id.

199 See Levit \& Linder, supra note 1, at 6; MCCLURG, supra note 1; Krieger, supra note 1; cf. Rosen, supra note 1, at 162 (commenting on how lawyers' depression appears to originate in law school).

${ }^{200}$ GiBB, supra note 25, at 187; MEYER \& QUENZER, supra note 103, at 563.

201 GIBB, supra note 25, at 188.

202 Id.

${ }^{203} I d$.

204 MEYER \& QUENZER, supra note 103, at 564.

205 George B. Richerson et al., The Modulatory Functions of the Brain Stem, in PRINCIPLES OF NEURAL SCIENCE, supra note 40, at 1038, 1040.

206 MEYER \& QuENZER, supra note 103, at 554-56.

207 GiBB, supra note 25, at 189.

208 Neil R. Carlson, Physiology of Behavior 58 (11 th ed. 2013). 
flushed out. ${ }^{209}$ Proper disposal of neurotransmitters is critical to neuron communication. ${ }^{210}$

All antidepressants increase the function of serotonin or norepinephrine, or both. ${ }^{211}$ Selective serotonin reuptake inhibitors ("SSRIs") work by leaving more serotonin in the synapse. ${ }^{212}$ Monoamine oxidase A ("MAO-A") is a protein that degrades serotonin, norepinephrine, and dopamine in the synapse, thus monoamine oxidase A inhibitors ("MAOIs") work by blocking the destruction of serotonin, norepinephrine, and dopamine. ${ }^{213}$

SSRIs block the reuptake of serotonin by the releasing neuron, making more serotonin available to stimulate the post-synaptic neuron. ${ }^{214}$ It takes several weeks for the brain to adapt to the new serotonin levels, but once it does, the lawyer's mood improves. ${ }^{215}$ Long-term treatment with SSRIs increases neurogenesis, the birth of new brain cells in the hippocampus, which may be influential to mood enhancement. ${ }^{216}$ It also increases production of brain-derived neurotropic factor ("BDNF"), an important neurotrophin that regulates neuron survival and synaptic changes in the lawyer brain. ${ }^{217}$ Antidepressants prevent stress-related BDNF reduction and neuron damage. ${ }^{218}$

With all the SSRIs except Prozac, there is an increased risk of suicide. ${ }^{219}$ They also cause sexual dysfunction, and withdrawal from SSRIs can cause headaches, diarrhea, and aggression. ${ }^{220}$

MAOIs increase serotonin, norepinephrine, and dopamine in the synapse by reducing transmitter extinction. ${ }^{221}$ MAOIs have serious side effects including insomnia, weight gain, and elevated blood pressure. ${ }^{222}$ MAOIs impact all systems in the body, thus some foods (certain cheeses, meats, and pickled products) and other drugs (cold medications, aspirin, amphetamine, alcohol, cocaine, opioids, and barbiturates) must be avoided because they could cause life-threatening high blood pressure or stroke. ${ }^{223}$

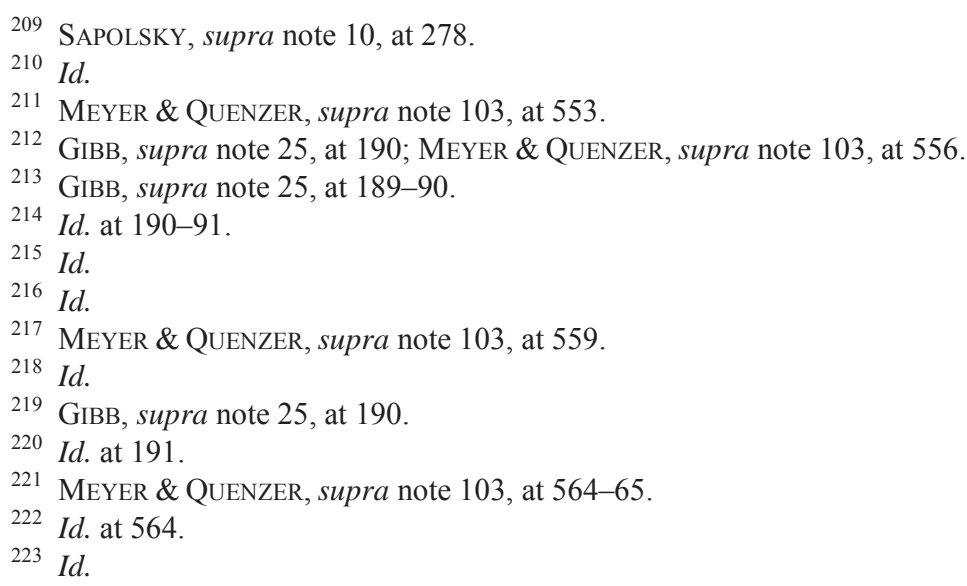




\section{B. Drugs of Abuse}

The National Survey on Drug Use and Health ("NSDUH") interviews about seventy thousand randomly-selected Americans who are twelve years or older each year. ${ }^{224}$ In 2012, 82 percent of Americans reported having used alcohol, 62 percent reported having smoked cigarettes, and 42 percent reported having used marijuana or hashish at least once. ${ }^{225}$

Illicit drug use is increasing among Americans. In the 2010 NSDUH study, approximately 22.6 million Americans age twelve or older had used an illicit drug in the last month. ${ }^{227}$ That represents 8.9 percent of Americans in that age range. ${ }^{228}$ In the 2012 NSDUH study, approximately 23.9 million Americans, or 9.2 percent of the U.S. population age twelve and older, used an illicit drug in the last month. ${ }^{229}$ Table 2 shows the percentage of 2012 NSDUH study participants who have used a drug of abuse at least once.

Lawyer goal-directed behavior involves the evaluation of the risks, costs,

\begin{tabular}{lr}
\multicolumn{2}{c}{ TABle 2: Drug Use Statistics } \\
\hline \hline \\
Type of Drug & \% Reporting \\
\hline Alcohol & 82.30 \\
Cigarettes & 61.90 \\
Smokeless Tobacco & 17.70 \\
Marijuana/Hashish & 42.80 \\
Pain Relievers & 14.20 \\
Stimulants & 8.30 \\
Cocaine & 14.50 \\
MDMA & 6.20 \\
Methamphetamine & 4.70 \\
Heroin & 1.80 \\
\hline
\end{tabular}
and benefits of any activity. ${ }^{230}$ Motivation and reward-seeking have a neural basis in the emotional and thinking brains. ${ }^{231}$ Motivation is a desire to obtain a

224 About the Survey, NAT'L Surv. ON Drug UsE \& HeAlth, https://nsduhweb.rti.org/respweb/project_description.html (last visited May 7, 2015).

${ }^{225}$ Ctr. For Behavioral Health Statistic \& Quality, Results from the 2012 Nat'L SuRveY ON DRUG USE \& HEALTH, http://archive.samhsa.gov/data/NSDUH/2012SummNat FindDetTables/DetTabs/NSDUH-DetTabsSect1peTabs1 to46-2012.htm\#Tab1.1B (last visited May 29, 2015); Ctr. For Behavioral Health Statistic \& Quality, Results from THE 2012 NAT'L SuRvey ON DRUg Use and Health, http://archive.samhsa .gov/data/NSDUH/2012SummNatFindDetTables/DetTabs/NSDUH-DetTabsSect2peTabs1 to 42-2012.htm\#Tab2.1B (last visited May 29, 2015).

${ }^{226}$ Nat'l Survey of Drug Use and Health, NAT'L Inst. ON DRUg ABuse, http://www.drugabuse.gov/national-survey-drug-use-health (last visited May 7, 2015).

227 Ctr. for Behavioral Health Statistic \& Quality, U.S. Dep't of Health \& Human Servs., Pub. No. (SMA) 11-4658, Results from the 2010 Nat'l Survey on Drug Use AND HeAlth: Summary OF NAT'L Findings 11 (2011), available at http://www.oas.samhsa.gov/NSDUH/2k10NSDUH/2k10Results.pdf.

${ }^{228} I d$.

229 Ctr. for Behavioral Health Statistic \& Quality, U.S. Dep't of Health \& Human Servs., Pub. No. (SMA) 13-4795, Results from the 2012 NAT'l Survey on Drug Use AND HeAlth: SUMmary OF NAT'L Findings 13 (2013), available at http://www.samhsa.gov/data/NSDUH/2012SummNatFindDetTables/NationalFindings /NSDUHresults2012.pdf.

230 Shizgal \& Hyman, supra note 123, at 1103.

231 CARTER ET AL., HumAn Brain, supra note 12, at 128. 
reward. ${ }^{232}$ A reward is an object, stimulus, or activity that has positive value and gives a lawyer pleasure. ${ }^{233}$ Some law students, law faculty, lawyers, and judges self-medicate with drugs of abuse as a response to stress, anxiety, and/or depression. The lawyer should understand what is known about the actions and impacts of mixed action drugs (alcohol, nicotine, cannabis), stimulants, opiates, sedatives, hallucinogens, and some foods on the lawyer brain.

Drugs that bind to and activate receptors are called agonists and drugs that bind to and block receptors are called antagonists. ${ }^{234}$ Some drugs are agonists because they mimic naturally-occurring endogenous substances in the lawyer brain. ${ }^{235}$ Neuroscientists are in the early stages of understanding the impacts of psychoactive drugs and various addictions. ${ }^{236}$ Most addictive substances hijack the dopamine system. ${ }^{237}$ The artificial activation of the dopamine system, and intense euphoria that accompanies use of drugs of abuse, can become the basis of addiction. ${ }^{238}$ Table 3 provides a taxonomy of the major classes of addictive drugs and their endogenous natural analogs.

\section{Mixed Action Drugs}

Mixed action drugs produce several different effects in the lawyer brain, and they include alcohol, nicotine, and cannabis. ${ }^{239}$

\section{a. Alcohol}

Alcohol is the second most widely used drug in America, surpassed only by caffeine. ${ }^{240}$ William Burroughs called alcohol "[o]ur national drug" in his 1959 novel Naked Lunch, ${ }^{241}$ and it is our most abused drug. ${ }^{242}$

The active ingredient in all alcoholic beverages is ethanol and its effects on the lawyer brain are quite complex. ${ }^{243}$ Alcohol is a mixed action drug because at low doses it begins as a stimulant that results in mild euphoria and has an anxiolytic impact, reducing the discomfort of anxiety. ${ }^{244}$ Later it has a depressant effect on neural activity. ${ }^{245}$ In higher amounts, it causes incoordination and sedation. ${ }^{246}$

232 MEYer \& QueNZER, supra note 103, at 250.

233 Shizgal \& Hyman, supra note 123, at 1104; see LINDEN, supra note 86, at 18.

234 PURVES ET AL., supra note 54, at 25.

235 See Linden, supra note 86, at 44.

236 MEYER \& QuENZER, supra note 103, at 250.

237 DoIDGE, supra note 7, at 106.

238 LINDEN, supra note 86, at 20.

239 LINDEN, supra note 86, at 41.

240 MEYER \& QUENZER, supra note 103, at 266.

241 William S. Burroughs, NaKed Lunch 224 (2001).

${ }^{242}$ MEYer \& QuenZER, supra note 103, at 266.

243 GIBB, supra note 25, at 184-85.

244 CARLSON, supra note 208, at 631; WATSON \& BREEDLOve, supra note 29, at 95.

245 WATSON \& BREEDLOVE, supra note 29, at 95.

246 CARLSON, supra note 208, at 631. 
TABLE 3: DRUG TAXONOMY ${ }^{247}$

\begin{tabular}{lll}
\hline \hline Drug & Source & Endogenous Analogs \\
\hline Mixed Action Drugs & & \\
\hline Alcohol & Tobacco & Acetylcholine \\
Nicotine & Cannabis & Endocannabinoids \\
Marijuana & & \\
Stimulants & Trimethylxanthine & Adenosine \\
\hline Caffeine & Coca Leaf & \\
Cocaine & Synthetic & \\
Amphetamine & \\
Opiates & Opium Poppy & Endorphins \\
Morphine, & \\
$\begin{array}{l}\text { Methadone, } \\
\text { Oxycodone, }\end{array}$ & \\
Heroin & \\
OxyContin, & Synthetic & \\
Fentanyl & \\
Sedatives & & \\
\hline Barbiturates & Synthetic & \\
Bendodiazepines & Synthetic \\
Hallucinogens & & \\
\hline LSD & & \\
Phencyclidine (“PCP”) & Synthetic & \\
\hline
\end{tabular}

Humans have been producing alcoholic beverages for over five thousand years ${ }^{248}$ using fermentation, a process where microscopic yeast cells fall from the air onto any substance containing sugar, such as honey, fruit, or grains. ${ }^{249}$ Fermentation of grapes yields wine, rice produces sake, and grains create beer. ${ }^{250}$ Fermentation continues until the yeast dies and the alcohol content is about 15 percent. ${ }^{251}$ Distillation is required to reach a higher alcohol content. ${ }^{252}$ The fermented mixture is heated and the alcohol vapor is cooled in a still and

247 LiNDEN, supra note 86, at 40-41, 44; Shizgal \& Hyman, supra note 123, at 1106.

248 GiBB, supra note 25, at 185.

249 Meyer \& Quenzer, supra note 103, at 267; WATSON \& BREEDlove, supra note 29, at 95.

250 MEYER \& QUENZER, supra note 103, at 267.

${ }^{251} I d$.

${ }^{252} I d$. 
collected as distilled spirits or hard liquor such as whiskey, rum, and tequila. ${ }^{253}$ Alcohol concentrations of hard liquor typically consumed in the United States are 40 percent to 50 percent. $^{254}$

The impact of alcohol is described in terms of blood alcohol concentration ("BAC"). ${ }^{255}$ The Centers for Disease Control and Prevention describes impacts on driving by BAC level:

- $\mathrm{BAC}$ at 0.02 percent

- Decline in visual tracking of moving objects

- Decline in the ability to perform two tasks at once

- $\mathrm{BAC}$ at 0.05 percent

$\circ$ Reduced coordination

- Trouble steering

- Reduced ability to track moving objects

- Reduced response to emergency driving situations

- $\quad$ BAC at 0.08 percent

- Impaired perception, concentration, and information processing

$\circ$ Impaired judgment and reasoning

- Less control over speed

- Short-term memory loss. ${ }^{256}$

The National Transportation Safety Board has proposed lowering the legal driving limit from a BAC of 0.08 percent to 0.05 percent to reduce alcoholrelated accidents and deaths. ${ }^{257}$

It has been thirty years since Congress passed the National Minimum Age Drinking Act, which prohibits people under twenty-one years of age from purchasing or possessing alcohol, and withholds federal highway funding from any state that does not conform to the minimum drinking age. ${ }^{258}$ The U.S. Department of Transportation estimates that 525 lives were saved in 2012 because of the minimum drinking age law. ${ }^{259}$ Impaired driving in 2012 caused more than ten thousand deaths, which is a rate of one death every fifty-one minutes. ${ }^{260}$

\footnotetext{
${ }^{253} I d$.

${ }^{254} I d$.

$255 I d$. at 268.

256 Effects of Blood Alcohol Concentration (BAC), CTRS. FOR Disease CONTROL \& PREVENTION, http://www.cdc.gov/Motorvehiclesafety/Impaired Driving/bac.html (last updated Jan. 13, 2015).

257 Mike M. Ahlers, Tougher Drunk-Driving Threshold Proposed to Reduce Traffic Deaths, CNN (May 15, 2013, 6:36 AM), http://www.cnn.com/2013/05/14/us/ntsb-blood-alcohol/. 25823 U.S.C. $\$ 158$ (2012).

259 Nat'l Highway Traffic Safety Admin., U.S. Dep't of Transp., Lives Saved in 2012 By RESTRAint Use AND Minimum Drinking Age LAWs 1 (2013), available at http://www-nrd.nhtsa.dot.gov/Pubs/811851.pdf. Estimate of lives saved in 2011 is 535, in 2010 is 552, in 2009 is 626, and in 2008 is 716. Id.

${ }^{260}$ Impaired Driving, NAT'L Highway TRAFFIC SAFETY ADMIN., http://www.nhtsa.gov /Impaired (last visited May 7, 2015).
} 
The National Institute on Alcohol Abuse and Alcoholism defines binge drinking as a pattern of drinking that brings the BAC up to 0.08 percent within two hours, which is about four drinks for women and five drinks for men. ${ }^{261}$ From 2010 to 2012, the national average for people ages twelve to twenty of alcohol binge use was 15.9 percent within thirty days of the survey, but the range from different geographical areas of the U.S. was from 9.17 percent to 46.32 percent. ${ }^{262}$ About four out of five college students drink, and two out of five participate in binge drinking. ${ }^{263}$ Students who drink risk injury, academic problems, health problems, and death. ${ }^{264}$ Other students are impacted by drinkers when they become victims of assault or sexual abuse. ${ }^{265}$

Binge drinking practices from undergraduate life may follow students into law school and law practice. One study found that where minimum drinking ages were lower than twenty-one years, adult males had significantly higher rates of alcohol use and were involved in more traffic fatalities. ${ }^{266}$ Binge drinking has been correlated with general anxiety disorders, especially for men. ${ }^{267}$ Binge drinking and alcohol overdose can be lethal, as demonstrated by the recent alcohol poisoning death of English singer Amy Winehouse in 2011. ${ }^{268}$ Drinking problems may begin in law school, where school events may teach students "to drink like a lawyer." ${ }^{269}$ Lawyers may drink to relieve stress and one study estimated that 15 percent of lawyers are alcoholics. ${ }^{270}$

Alcohol is bioavailable, readily absorbed from the gastrointestinal ("GI") tract, distributed by the blood, and introduced into the brain. ${ }^{271}$ The neurochem-

261 Drinking Levels Defined, NAT'L InSt. ON Alcohol ABuse \& Alcoholism, http:// www.niaaa.nih.gov/alcohol-health/overview-alcohol-consumption/moderate-binge-drinking (last visited May 7, 2015).

${ }^{262}$ Ctr. for Behavioral Health Statistics \& Quality, U.S. Dep't of Health \& Human Servs., The NSDUH Report: Underage Binge Alcohol Use Varies Within and ACross STATES 2 (2014), available at http://www.samhsa.gov/data/2K14/NSDUH199 /sr199-underage-binge-drinking-2014.pdf.

263 College Drinking, NAT'L InST. ON Alcohol ABUSE \& Alcoholism, http://www .niaaa.nih.gov/alcohol-health/special-populations-co-occurring-disorders/college-drinking (last visited May 7, 2015).

264 Id.

265 Id.

266 Robert Kaestner \& Benjamin Yarnoff, Long-Term Effects of Minimum Legal Drinking Age Laws on Adult Alcohol Use and Driving Fatalities, 54 J.L. \& ECON. 365, 367 (2011).

267 James A. Cranford et al., Substance Use Behaviors, Mental Health Problems, and Use of Mental Health Services in a Probability Sample of College Students, 34 Addictive BeHAvs. 134, 142 (2009).

268 MCKIM \& HANCOCK, supra note 126, at 152.

269 MCCLURG, supra note 1, at 321.

270 Bridget A. Maloney, Note, Distress Among the Legal Profession: What Law Schools Can Do About It, 15 Notre Dame J.L. EThics \& PUB. PoL'Y 307, 320 (2001).

${ }^{271}$ MEYER \& QUENZER, supra note 103, at 268. 
ical effects of alcohol are complex because alcohol acts on multiple neurotransmitters: GABA, glutamate, dopamine, and endorphins. ${ }^{272}$

Alcohol binds to neurons that allow the amplification of the neurotransmitter GABA. ${ }^{273}$ Alcohol is an indirect agonist at the GABA receptors, increasing the post-synaptic response to GABA. ${ }^{274}$ The calming and sedating effects of alcohol are due to increased GABA, ${ }^{275}$ which is an inhibitory transmitter responsible for slowing or stopping synaptic firing. ${ }^{276}$ GABA is the synaptic transmission brake. ${ }^{277}$ The result is some degree of drunkenness producing reduced anxiety, social disinhibition, poor motor control, and sensory problems. ${ }^{278}$

Alcohol also interferes with the transmission of glutamate. ${ }^{279}$ Glutamate is a major excitatory transmitter. ${ }^{280}$ Alcohol acutely inhibits glutamate by reducing its effectiveness, even at a social drinker BAC level of 0.03 percent. ${ }^{281} \mathrm{Al}-$ cohol, like other glutamate antagonists, impairs learning and memory, and disrupts long-term potentiation. ${ }^{282}$ Alcohol also prevents neurogenesis, the birth of new neurons, in the hippocampus. ${ }^{283}$ Alcohol reduces glutamate release in the hippocampus, weakening spatial memory. ${ }^{284}$ When the brain experiences a reduction in glutamate due to regular alcohol use, it responds by up-regulating, or increasing the number of receptors. ${ }^{285}$ When alcohol use is reduced, the increased glutamate activation at the additional receptors is responsible for the dangerous seizures associated with alcohol withdrawal and the cell death responsible for brain damage in alcoholics. ${ }^{286}$

Like other addictive drugs, alcohol increases the release of dopamine in the NAC. ${ }^{287}$ Alcohol also triggers the release of the body's endogenous opioids, endorphins. ${ }^{288}$ Dopamine is responsible for the reinforcing effects, and opiate

272 MCKIM \& HANCOCK, supra note 126, at 306; MEYER \& QUENZER, supra note 103, at 283-90.

${ }^{273}$ BROAD, supra note 54, at 202.

274 CARLSON, supra note 208, at 631-33.

275 CARLSON, supra note 208, at 633.

276 CARLSON, supra note 208, at 122.

277 Id.

278 WATSON \& BREEDLOVE, supra note 29, at 95.

279 CARLSON, supra note 208, at 632.

280 MCKim \& HANCOCK, supra note 126, at 141; MEYER \& QuENZER, supra note 103, at 285.

281 MEYER \& QUENZER, supra note 103, at 285.

282 CARLSON, supra note 208, at 632; MCKIM \& HANCOCK, supra note 126, at 141; MEYER \& QUENZER, supra note 103, at 285.

283 MCKIM \& HANCOCK, supra note 126, at 141.

284 CARLSON, supra note 208, at 632.

285 MCKIM \& HANCOCK, supra note 126, at 141; MEYER \& QUENZER, supra note 103, at 285.

286 MEYER \& QUENZER, supra note 103, at 285.

287 CARLSON, supra note 208, at 632; MEYER \& QUENZER, supra note 103, at 287.

288 CARLSON, supra note 208, at 633; MCKIM \& HANCOCK, supra note 126, at 147; MEYER \& QUENZER, supra note 103, at 289. 
receptors are critical to the rewarding impacts of alcohol. ${ }^{289}$ The opiate receptor blockers naloxone and naltrexone prevent the effects of alcohol in rats, monkeys, and humans. ${ }^{290}$

Research has linked chronic alcohol consumption to shrinkage of brain volume. ${ }^{291}$ Heavy alcohol use causes a deficiency in vitamin B1 (thiamine), which is critical for brain glucose metabolism, and low levels of thiamine cause brain cell death. ${ }^{292}$ Those who abstain from alcohol were found to have greater brain volume than former drinkers and moderate drinkers. ${ }^{293}$ Alcoholics have brain shrinkage in the following areas:

- Frontal lobes, causing apathy, disinhibition, and diminished executive function;

- Hippocampus, causing memory problems; and

- Cerebellum, causing incoordination. ${ }^{294}$

A lawyer does not have to drink heavily for years to induce impairment of cognition and damage to the brain. ${ }^{295}$ A study of college students, age eighteen to twenty years old, who periodically participated in binge drinking showed verbal memory deficits, indicating damage to the hippocampus. ${ }^{296}$

\section{b. Nicotine}

Nicotine is derived from the tobacco plant and it is the third most widely used recreational drug behind caffeine and alcohol. ${ }^{297}$ Tobacco was smoked, chewed, and brewed in tea by the indigenous peoples of the Americas, and Christopher Columbus brought it from the Bahamas to Europe in $1492 .{ }^{298}$ The British brought tobacco to its Virginia colony giving birth to the American tobacco industry, and in 1884 the first cigarette machine was built. ${ }^{299}$ Modern technology produces 4,000 to 8,000 cigarettes per minute. ${ }^{300}$

Smoking is an extremely efficient method of drug delivery and nicotine is delivered to the brain in seven seconds via cigarette smoke. ${ }^{301}$ Nicotine enters the lawyer's lungs on tiny hydrocarbon tar particles, in a chemical mixture con-

289 CARLSON, supra note 208, at 632-33; MCKIM \& HANCOCK, supra note 126, at 147; MEYER \& QUENZER, supra note 103, at 287, 289.

${ }^{290}$ CARLSON, supra note 208, at 633.

291 CARTER ET AL., Human Brain, supra note 12, at 44; MCKim \& HANCOCK, supra note 126, at 154; MEYER \& QUENZER, supra note 103, at 277; SwEENEY, supra note 15, at 200.

292 MCKIM \& HANCOCK, supra note 126, at 154; MEYER \& QUENZER, supra note 103, at 276.

293 CARTER ET AL., HumAn Brain, supra note 12, at 44.

294 MCKIM \& HANCOCK, supra note 126, at 154; MEYER \& QUENZER, supra note 103, at 277.

295 MCKIM \& HANCOCK, supra note 126, at 154.

296 Id.

297 GiBB, supra note 25, at 194; MEYER \& QUENZER, supra note 103, at 374.

298 GiBB, supra note 25, at 194; MEYER \& QUENZER, supra note 103, at 373.

299 MEYER \& QUENZER, supra note 103, at 374.

$300 I d$. at 375.

${ }^{301} I d$. 
taining known carcinogens. ${ }^{302}$ An average cigarette delivers ten puffs of nicotine and a smoker who consumes one and a half packs per day gets about 300 hits of nicotine daily. ${ }^{303}$ Nicotine stays in the lawyer's system for about two hours; thus, withdrawal symptoms keep the lawyer smoking at regular intervals. ${ }^{304}$

Nicotine impacts cognitive processes including attention and memory. ${ }^{305}$ Nicotine impacts mood and appetite, and suppresses the REM sleep cycle. ${ }^{306}$ It is a mixed action drug because it produces varying behavioral and physiological effects for smokers, and differences in smokers and non-smokers. ${ }^{307}$ In nonsmokers, nicotine can increase anxiety, dizziness, and nausea. ${ }^{308}$ It can also improve cognitive and motor function. ${ }^{309}$ For smokers, nicotine administration is thought to relieve withdrawal symptoms, but it can also improve attention. ${ }^{310}$

Nicotine engages the dopamine system from the VTA to the NAC, and thus is highly addictive. ${ }^{311}$ Other drugs that activate the dopamine pathway include alcohol, ${ }^{312}$ cannabis, ${ }^{313}$ cocaine and amphetamine, ${ }^{314}$ and heroin. ${ }^{315}$ Research has shown that humans, non-human primates, rats, mice, and dogs will all self-administer nicotine to receive its rewarding effects. ${ }^{316}$ Nicotine is an acetylcholine receptor agonist. ${ }^{317}$ It binds to the neurotransmitter acetylcholine receptors, which excite the glutamate receptors in the VTA, causing dopamine release in the NAC. ${ }^{318}$

Nicotinic acetylcholine receptors activate parts of both the fight-or-flight SNS and the rest-and-digest PNS. ${ }^{319}$ In activating the SNS, nicotine is a potent

$302 I d$.

303 Id.

$304 I d$. at 376.

305 PURVES ET AL., supra note 54, at 23, 25.

306 Horstman, Day IN THE Life, supra note 11, at 170; PURVES ET AL., supra note 54, at 23, 25.

${ }^{307}$ MEYER \& QUENZER, supra note 103, at 377.

308 Id.

${ }^{309}$ Id. at $377-79$.

$310 \mathrm{Id}$. at 377,379

311 BEAR ET AL., supra note 53, at 568-69; MCKIM \& HANCOCK, supra note 126, at 191; MEYER \& QuENZER, supra note 103, at 379-80; SwEENEy, supra note 15, at 201; George F. Koob et al., Reward, Motivation, and Addiction, in Fundamental Neuroscience, supra note 54 , at 871,886 .

312 CARLSON, supra note 208, at 632.

$313 I d$. at 633

314 BEAR ET AL., supra note 53, at 568-69; CARLSON, supra note 208, at 627; SwEENEY, supra note 15 , at 201.

315 BEAR ET AL., supra note 53, at 569; CARLSON, supra note 208, at 625; SwEENEY, supra note 15 , at 201.

316 MEYer \& QUENZER, supra note 103, at 379.

317 BEAR ET AL., supra note 53, at 150; Koob et al., supra note 311.

318 LiNDEN, supra note 86, at 44, 46; WATSON \& BREEDLOVE, supra note 29, at 95; Koob et al., supra note 311 .

319 MEYER \& QUENZER, supra note 103, at 381. 
stimulant, ${ }^{320}$ increasing alertness, heart rate, blood pressure, and digestion. ${ }^{321}$ This activation can increase a smoker's risk for heart disease and stroke. ${ }^{322}$ It constricts blood vessels in the skin, likely causing the skin to wrinkle and age faster than that of nonsmokers. ${ }^{323}$ Nicotine increases stomach acid and muscle contraction in the bowels, which can cause stomach ulcers, diarrhea, and irritable bowel. ${ }^{324}$

Nicotine is highly toxic and nicotine poisoning can occur if tobacco is swallowed or exposed to skin in tobacco fields. ${ }^{325}$ Nicotine poisoning causes nausea, vomiting, diarrhea, headaches, dizziness, confusion, hearing and vision problems, weakness, drop in blood pressure, breathing difficulty, and collapse. ${ }^{326}$ Victims of nicotine poisoning are treated for shock, induced to vomit, given charcoal to absorb nicotine in the stomach, and helped to breathe. ${ }^{327}$

More people in the United States die of smoking-related lung cancer each year than from colon, breast, and prostate cancers combined. ${ }^{328}$ Smoking cigarettes increases the risk of cancer, heart disease, stroke, hardening of the arteries, emphysema, and chronic bronchitis. ${ }^{329}$ Nicotine is so addictive, many people refuse to stop smoking, even after the onset of serious illness. ${ }^{330}$ Sigmund Freud, a doctor who knew smoking caused a cancer that resulted in the removal of most of his jaw, did not quit smoking. ${ }^{331}$

When smokers quit, they experience deterioration in mood for three to four weeks, when mood then returns to the pre-cessation state. ${ }^{332}$ But mood improves during the next ten weeks, becoming better than during smoking. ${ }^{333}$

\section{c. Cannabis}

Marijuana and hashish (cannabis) are produced from the Cannabis sativa plant, also known as the flowering hemp. ${ }^{334}$ Marijuana and hashish can be smoked, or eaten in edibles such as cookies, brownies, or candy. ${ }^{335}$ Cannabis is

320 Richerson et al., supra note 205, at 1041.

321 MeYer \& Quenzer, supra note 103, at 381; WATSON \& BREEDLOVE, supra note 29, at 94.

322 MeYer \& QueNZER, supra note 103, at 381.

323 MCKIM \& HANCOCK, supra note 126, at 191.

324 Id.; MEYER \& QUENZER, supra note 103, at 381.

325 MEYER \& QUENZER, supra note 103, at 381.

${ }^{326} \mathrm{Id}$.

327 Id.

328 WATSON \& BREEDLOVE, supra note 29, at 100.

329 MCKIM \& HANCOCK, supra note 126, at 201-03; MEYER \& QUENZER, supra note 103, at 390.

${ }^{330}$ CARLSON, supra note 208, at 628.

331 Id.

332 MCKIM \& HANCOCK, supra note 126, at 192.

${ }^{333} \mathrm{Id}$.

334 GiBB, supra note 25, at 215; MEYER \& QUENZER, supra note 103, at 402.

335 MeYer \& QuENZER, supra note 103, at 402. 
a mixed action drug because it is a depressant, but can act as a mild hallucinogenic and stimulant, occasionally causing paranoia. ${ }^{336}$

Synthetic cannabinoids have been produced to treat anorexia, weight loss in AIDS patients, and chemotherapy-related nausea in cancer patients. ${ }^{337} \mathrm{Sev}$ eral synthetic cannabinoids produced for recreational use, such as Spice and $\mathrm{K} 2$, are illegal. ${ }^{338}$

Cannabis likely originated in Asia and was used for medical and religious purposes in China, India, and the Middle East. ${ }^{339}$ Hashish made its way to France via Napoleon's soldiers, or the French doctor Jacques-Joseph Moreau, who helped found a hashish club for artists and writers that included Victor Hugo, Alexandre Dumas, and Charles Baudelaire. ${ }^{340}$ Hemp was grown in the U.S. colonies, perhaps most famously by George Washington, but not consumed for intoxication. ${ }^{341}$ The practice of smoking cannabis was probably influenced by immigrants from Mexico and the Caribbean in the early 1900s. ${ }^{342}$

Cannabis is a controversial drug because it is gradually being decriminalized and inconsistent research results have made conclusions about potential harm difficult to interpret. ${ }^{343}$ The consumption of cannabis for recreational purposes has been approved in Colorado, ${ }^{344}$ Washington, ${ }^{345}$ Alaska, ${ }^{346}$ Oregon, ${ }^{347}$ and Washington, DC, ${ }^{348}$ but these state laws conflict with federal law, which makes cannabis consumption illegal. ${ }^{349}$ Twenty states and Washington, D.C. allow consumption of cannabis for medical purposes. ${ }^{350}$

Delta-9-tetrahydrocannabinol ("THC") gives cannabis products their psychoactive properties. ${ }^{351}$ Another group of chemical compounds called cannabinoids may also contribute to the drug effects of cannabis. ${ }^{352}$ When marijuana is smoked, it is readily absorbed through the lungs, which absorb about 20 per-

\footnotetext{
336 Linden, supra note 86, at 41; WATSON \& BREEDLOVE, supra note 29, at 96.

337 MCKIM \& HANCOCK, supra note 126, at 314-15.

$338 I d$. at 315.

339 MEYER \& QUENZER, supra note 103, at 403.

${ }^{340} \mathrm{Id}$.

341 Id.

342 Id.

343 MCKIM \& HANCOCK, supra note 126, at 327.

344 Colo. Const. art. XVIII, $\S 16$.

345 Wash. ReV. CODE $\$ \S 69.50 .360,69.50 .4013$ (2014).

346 Alaska Stat. $\$ 17.38 .010$ (2015).

347 Oregon Control, Regulation, and Taxation of Marijuana and Industrial Hemp Act, 2014 Ballot Measure 91 (Or. 2015).

348 D.C. CODE $§ 48-904.01$ (2014).

34921 U.S.C. $\$ 812$ (2012).

${ }^{350}$ Marijuana Resource Center: State Laws Related to Marijuana, OfFICE OF NAT'L DRUG CONTROL POLICY, http://www.whitehouse.gov/ondcp/state-laws-related-to-marijuana (last visited May 8, 2015).

351 GiBB, supra note 25, at 215; Meyer \& QUENZER, supra note 103, at 402.

352 MCKIM \& HANCOCK, supra note 126, at 314.
} 
cent to 30 percent of the THC. ${ }^{353}$ THC levels in the blood decline fairly rapidly, but complete elimination of the drug is much slower because it persists in fat tissue where it can be detected in urine tests for more than two weeks after a single marijuana use. ${ }^{354}$

Administration of THC to mice results in reduced activity, decreased body temperature, reduced pain sensitivity, and spatial learning deficits. ${ }^{355}$ When lawyers smoke marijuana, they can experience effects ranging from lightheadedness, euphoria, disinhibition, and relaxation, to hallucinations. ${ }^{356} \mathrm{THC}$ increases blood flow to the skin causing warmth or flushing, increases heart rate, and stimulates appetite. ${ }^{357}$ High doses of cannabis can cause agitation, a feeling of being separated from oneself, a sense that the world is unreal, and paranoia. ${ }^{358}$ Cannabis also interferes with normal stages of sleep. ${ }^{359}$

Cognitive problems caused by cannabis include deficits in verbal, spatial, time estimation, and reaction time tasks. ${ }^{360}$ Cannabis interferes with all aspects of memory processing: encoding, consolidation, and retrieval. ${ }^{361}$ It disrupts hippocampus function, important to memory formation. ${ }^{362}$ One study showed high levels of cannabis use in adolescence resulted in a reduction of volume of the right hippocampus. ${ }^{363}$ Long-term impacts of cannabis use are still under investigation, but studies show executive function is impaired in long-term users for two to three weeks after cessation. ${ }^{364}$ Executive function can be compared to a switch operator controlling the pattern of tracks at a busy railroad. ${ }^{365}$ Executive functions are supervisory or regulatory, such as planning, processing options, guiding sensory information flow, initiating motor action, and inhibiting inappropriate responses. ${ }^{366}$ Psychomotor performance is impaired under demanding task conditions like driving following a moderate or high dose of cannabis, or when a low dose of cannabis is combined with alcohol. ${ }^{367}$

Researchers are very interested in the impact of cannabis on educational performance. A study of approximately 1,000 New Zealanders who were re-

353 MEYER \& QuENZER, supra note 103, at 404.

${ }^{354} \mathrm{Id}$.

$355 I d$. at 406.

356 MCKIM \& HANCOCK, supra note 126, at 319; MEYER \& QUENZER, supra note 103, at 413-14.

357 MCKIM \& HANCOCK, supra note 126, at 319; MEYER \& QUENZER, supra note 103, at 414.

358 MCKIM \& HANCOCK, supra note 126, at 320, 328; MEYER \& QUENZER, supra note 103, at 414.

359 MCKIM \& HANCOCK, supra note 126 , at 319.

360 MEYER \& QUENZER, supra note 103, at 415.

361 MCKIM \& HANCOCK, supra note 126, at 328; MEYER \& QUENZER, supra note 103, at 415.

362 CARLSON, supra note 208, at 635; WATSON \& BREEDlove, supra note 29, at 96.

363 MCKIM \& HANCOCK, supra note 126, at 322.

364 MEYer \& QueNZER, supra note 103, at 416.

365 PURVES ET AL., supra note 54, at 437.

366 MEYER \& QUENZER, supra note 103, at 367; PURVES ET AL., supra note 54, at 431.

367 MEYER \& QUENZER, supra note 103, at 416. 
cruited at age three were subject to neuropsychological testing at age thirteen prior to cannabis use, and again at age thirty-eight. ${ }^{368}$ At age thirty-eight, the amount of cannabis use and dependence were significantly associated with cognitive impairment, including lower IQ, even after controlling for education level. ${ }^{369}$ Amotivational syndrome, which includes symptoms such as apathy, aimlessness, decreased productivity, reduction of long-range planning, and loss of achievement motivation has been found in chronic cannabis users in thirty years of research. ${ }^{370}$ Cannabis use has been correlated with reduced educational achievement, and it has been established that cannabis impacts attention and memory. ${ }^{371}$

Brain imaging studies indicate abnormalities in the hippocampus and anterior cingulate cortex of chronic cannabis users. ${ }^{372}$ Chronic use has also been linked to the development of schizophrenia, chronic cough, bronchitis, and precancerous cells in bronchial biopsy samples. ${ }^{373}$ Activation of cannabinoid receptors suppresses immune function and interferes with the reproductive systems in both men and women. ${ }^{374}$ Marijuana smoke contains 50 percent to 70 percent more carcinogens than tobacco smoke and marijuana smoke is typically held longer in the lungs. ${ }^{375}$ Although the median age for developing cancer is between fifty-five and sixty-five years, one study of lung cancer patients under forty-five found that nearly all of them smoked both marijuana and tobacco. ${ }^{376}$

Endogenous means produced from within, ${ }^{377}$ and the brain produces endogenous cannabinoids. ${ }^{378}$ Endogenous cannabinoids modulate pain perception and play a role in hunger. ${ }^{379}$ Cannabinoid receptor antagonists that block the receptors reduce food consumption in animals and humans. ${ }^{380}$ Thus, the cannabinoid system is a target of pain control and obesity research. ${ }^{381}$

Cannabinoid $\mathrm{CB}_{1}$ receptors in the brain are in the cerebral cortex, hippocampus, cerebellum, striatum, and basal ganglia. ${ }^{382}$ Cannabinoid $\mathrm{CB}_{2}$ receptors have been discovered in the central nervous system, the immune system, the GI tract, bones, and fat cells. ${ }^{383}$ Activation of cannabinoid receptors inhibits the

368 Id. at 422

$369 \mathrm{Id}$.

$370 \mathrm{Id}$.

371 MCKIM \& HANCOCK, supra note 126, at 329.

372 MEYer \& QueNZER, supra note 103, at 423.

${ }^{373} \mathrm{Id}$.

374 Id.

375 MCKIM \& HANCOCK, supra note 126, at 330.

${ }^{376} \mathrm{Id}$.

377 CARLSON, supra note 208, at 124.

378 MCKIM \& HANCOCK, supra note 126, at 318; MEYER \& QUENZER, supra note 103, at 407.

379 MEYer \& QuENZER, supra note 103, at 409.

${ }^{380}$ Id.

$381 \mathrm{Id}$.

382 MCKIM \& HANCOCK, supra note 126, at 317; MEYER \& QUENZER, supra note 103, at 405.

383 MCKIM \& HANCOCK, supra note 126, at 317; MEYER \& QUENZER, supra note 103, at 405. 
release of the inhibitory neurotransmitter GABA and the excitatory neurotransmitter glutamate. ${ }^{384}$ Cannabinoids can also inhibit the release of acetylcholine, serotonin, norepinephrine, and dopamine. ${ }^{385}$

THC has a stimulating effect on dopamine neurons, causing release of dopamine in the NAC ${ }^{386}$ Opioid systems appear to play a role in the reward and feelings of pleasure associated with THC use because studies have found that opioid agonists enhance THC self-administration and opioid antagonists decrease THC self-administration in animals. ${ }^{387}$ Research suggests that the endocannabinoid system, via $\mathrm{CB}_{1}$ and $\mathrm{CB}_{2}$ receptors, may play a significant role in reinforcement, dependence, and/or relapse for nicotine, alcohol, opioids, and cocaine. ${ }^{388}$

\section{Stimulants}

Stimulants increase wakefulness and enhance mental function. ${ }^{389}$ Some common stimulants are caffeine, cocaine, and amphetamines (including Adderall and Ritalin).

\section{a. Caffeine}

Caffeine, one of the most commonly used drugs in the world, is present in coffee beans, tea leaves, soda, energy drinks, and chocolate. ${ }^{390}$ Caffeine increases arousal, improves concentration, and enhances sports performance. ${ }^{391}$ When the lawyer starts her day with coffee, caffeine blocks adenosine receptors in her brain. ${ }^{392}$ Adenosine is a neurotransmitter responsible for inducing sleep. ${ }^{393}$ Caffeine is an antagonist that sits on the adenosine receptor, blocking it and keeping it from promoting sleep. ${ }^{394}$ Caffeine has a complex relationship with dopamine, which involves interaction with adenosine, dopamine, and cannabinoid receptors. ${ }^{395}$ It stimulates dopamine release in the brain, ${ }^{396}$ and that impacts glutamate and acetylcholine. ${ }^{397}$ Recently, three substances have been identified in chocolate that are similar to the endogenous cannabinoids in the

384 SwEENEY, supra note 15 , at 200.

385 MEYER \& QUENZER, supra note 103, at 406.

386 MCKIM \& HANCOCK, supra note 126, at 318; MEYER \& QUENZER, supra note 103, at 417.

387 MEYER \& QUENZER, supra note 103, at 417.

388 MCKIM \& HANCOCK, supra note 126, at 319; MEYER \& QUENZER, supra note 103, at 417.

389 LINDEN, supra note 86, at 40.

390 MEYER \& QUENZER, supra note 103, at 393-94.

391 Id. at 395.

392 GiBB, supra note 25, at 194; MCKim \& HANCOCK, supra note 126, at 216; MEYER \& QUENZER, supra note 103, at 397, 399.

393 GiBB, supra note 25, at 194; MEYER \& QuENZER, supra note 103, at 399.

394 BEAR ET AL., supra note 53, at 671; GiBB, supra note 25, at 194.

395 MCKIM \& HANCOCK, supra note 126, at 217.

396 GiBB, supra note 25, at 194; MCKIM \& HANCOCK, supra note 126, at 216.

397 MCKIM \& HANCOCK, supra note 126, at 217. 
brain. ${ }^{398}$ The presence of endocannibinoids may explain the pleasure lawyers get from both coffee and chocolate. ${ }^{399}$

The therapeutic benefits of caffeine include its ability to improve the effectiveness of over-the-counter analgesics like Anacin and Excedrin and to treat newborn babies who stop breathing. ${ }^{400}$ When the lawyer over-consumes energy drinks or coffee, excess caffeine can cause agitation, insomnia, tremors, seizures, gastrointestinal distress, heart palpitations, respiratory problems, and cardiac arrest. $^{401}$

\section{b. Cocaine}

Cocaine is derived from the South American coca plant and was chewed or brewed in tea by indigenous people to ease pain, improve mood, and alleviate hunger. ${ }^{402}$ In the 1880 s, cocaine was used as an anesthetic and added to the original Coca-Cola soda. ${ }^{403}$ Sigmund Freud, a cocaine user, promoted cocaine to help people work longer and harder without tiring and to treat alcoholism and depression. ${ }^{404}$

If a lawyer ingested cocaine, it would interact with three neurotransmitters in the lawyer brain: dopamine, serotonin, and norepinephrine. ${ }^{405}$ Cocaine binds to the transporters for these three transmitters and prevents them from reuptake by the pre-synaptic neuron. ${ }^{406}$ Transporters are responsible for clearing the transmitters from the synapse for recycling by the presynaptic neuron. ${ }^{407}$ This leaves dopamine, serotonin, and norepinephrine to linger in the synaptic cleft and activate the receptors on the post-synaptic neuron. ${ }^{408}$

Cocaine does not interact with the three transporters equally. ${ }^{409}$ It has the highest affinity (binds most strongly) with the serotonin receptor, followed by the dopamine and finally the norepinephrine transporters. ${ }^{410}$ But cocaine does more than block the reuptake of dopamine, it also stimulates the release of dopamine in the NAC and amygdala. ${ }^{411}$ When dopamine receptors in the NAC

398 Id.

399 Id.

400 MEYer \& QuenZER, supra note 103, at 397.

401 GiBB, supra note 25, at 194; MEYER \& QUENZER, supra note 103, at 398.

402 GiBB, supra note 25, at 197-98; WATSON \& BREEDLOVE, supra note 29, at 97.

403 GiBB, supra note 25, at 198; WATSON \& BREEDlove, supra note 29, at 97.

${ }^{404}$ GIBB, supra note 25, at 198; MEYER \& QUENZER, supra note 103, at 339-41.

405 MEYER \& QUENZER, supra note 103, at 343.

406 MCKIM \& HANCOCK, supra note 126, at 233; MEYER \& QUENZER, supra note 103, at 343; SWEENEY, supra note 15, at 48; Shizgal \& Hyman, supra note 123, at 1106.

407 BEAR ET AL., supra note 53, at 158.

408 GiBB, supra note 25, at 32; MCKIM \& HANCOCK, supra note 126, at 233; MeYER \& QUENZER, supra note 103, at 343.

409 MEYER \& QUENZER, supra note 103, at 344.

410 Id.

411 BEAR ET AL., supra note 53, at 547; MCKIM \& HANCOCK, supra note 126, at 235; Koob, supra note 311 , at 884 . 
and amygdala are blocked by antagonists, rats will stop self-administration of both cocaine and amphetamine. ${ }^{412}$ Thus, the acute reinforcing effects of cocaine are due to dopamine. ${ }^{413}$ Because naltrexone, an opioid antagonist, reduces craving and use for several amphetamines, the subjective pleasure from cocaine use likely involves opioid and/or endocannabinoid receptors. ${ }^{414}$

Cocaine use in lawyers causes euphoria and suppresses hunger and fatigue. ${ }^{415}$ It increases alertness and self-confidence. ${ }^{416}$ It is a sympathomimetic drug, meaning that it produces symptoms of fight-or-flight SNS activation. ${ }^{417}$ Cocaine use causes increased heart rate and blood pressure, elevated body temperature, and narrowing of blood vessels. ${ }^{418}$ Low cocaine doses are usually not harmful, but the risks of heavy cocaine use include seizures, heart failure, stroke, and brain hemorrhage. ${ }^{419}$ It is possible for a single cocaine dose to trigger a stroke or seizure. ${ }^{420}$

Recent rodent research has shown that the narrowing of blood vessels during cocaine administration can significantly interrupt blood flow to the brain and this impact is intensified with repeated drug use. ${ }^{421}$ Cognitive deficits in cocaine-dependent lawyers include thinking brain weaknesses in inhibitory control and evaluation of consequences. ${ }^{422}$ Imaging studies in monkeys demonstrate increased prefrontal cortex thinking brain cognitive deficits with repeated cocaine exposure as compared to initial dosing. ${ }^{423}$ Human imaging studies show decreased volume in some areas of the thinking brain, as well as abnormalities in both gray and white matter in the cerebral cortex. ${ }^{424}$

412 Koob et al., supra note 311 , at 883 .

413 Id.

414 MCKIM \&HANCOCK, supra note 126, at 252.

415 Koob et al., supra note 311 , at 883 .

416 BEAR ET AL., supra note 53, at 546.

417 Id. at 547; MCKIM \& HANCOCK, supra note 126, at 235; MEYER \& QUENZER, supra note 103, at 346; Koob et al., supra note 311 , at 883 .

418 BEAR ET AL., supra note 53, at 547; MEYER \& QUENZER, supra note 103, at 346.

419 MEYER \& QUENZER, supra note 103, at 346.

${ }^{420} I d$. at 358 . The most famous case of a seizure and death from cocaine-related cardiac arrest is that of college basketball star Len Bias in 1986. Keith Harriston \& Sally Jenkins, Maryland Basketball Star Len Bias Is Dead at 22: Traces of Cocaine Found in System, WASH. POST (Jun. 20, 1986), http://www.washingtonpost.com/wp-srv/sports/longterm /memories/bias/launch/bias1.htm.

421 MEYER \& QUENZER, supra note 103, at 346.

422 Id. at 353 .

$423 \mathrm{Id}$.

${ }^{424} I d$. at 358 . 


\section{c. Amphetamine (including methamphetamine, mephedrone, Ritalin, and Adderall)}

Amphetamine is a synthetic stimulant with a chemical structure that closely resembles dopamine. ${ }^{425}$ Two similar plant compounds are khat, an evergreen shrub found in East Africa and the Arabian peninsula, and ephedrine from the herb Ephedra. ${ }^{426}$ Weight loss supplements contained ephedrine, but it produces sympathomimetic symptoms including increased blood pressure and risk of stroke or heart attack. ${ }^{427}$ Ephedrine was used in asthma medicine because it also widens bronchial airways. ${ }^{428}$ Some decongestants contain pseudoephedrine and they are closely regulated because they can be synthesized to create methamphetamine. $^{429}$

Amphetamine was synthesized in 1887 because doctors were seeking a synthetic substitute for ephedrine. ${ }^{430}$ Amphetamine was used to relieve nasal congestion and to treat narcolepsy, and by the military to keep pilots awake on long flights. ${ }^{431}$

Methamphetamine has a more powerful impact on the nervous system than amphetamine, ${ }^{432}$ but it produces similar neurochemical and behavioral effects. ${ }^{433}$ Other members of the amphetamine family are 3,4methylenedioxymethamphetamine ("MDMA", "Ecstasy"), 3,4methylenedioxyamphetamine ("MDA"), and 3,4-methylenedioxy-N-ethylamphetamine ("MDE"). ${ }^{434}$ This article will use the term "amphetamine" as a label for this group of drugs.

Amphetamine works by blocking the reuptake of norepinephrine, serotonin, and dopamine, and by stimulating the release of dopamine. ${ }^{435}$ Amphetamine uses the dopamine transporter, intended to remove and recycle dopamine by the presynaptic neuron, to enter the neuron and stimulate the release of addi-

$425 I d$. at 362 .

${ }^{426} \mathrm{Id}$.

${ }^{427}$ Id. at 362-63. Baltimore Orioles pitcher Steve Bechler collapsed and died at spring training in 2003. After it was discovered that he had been taking high doses of a weight loss supplement containing ephedra, the FDA banned sales in 2004. Id. at 363.

$428 I d$. at 363 .

429 Id. at 363 n. 4 .

430 GiBB, supra note 25, at 196; MeYER \& QuENZER, supra note 103, at 363.

431 BEAR ET AL., supra note 53, at 547; GIBB, supra note 25, at 196-97; MEYER \& QUENZER, supra note 103 , at 363 .

432 MEYER \& QuENZER, supra note 103, at 364.

$433 I d$. at 363 .

434 Id. at 362; Methylenedioxymethamphetamine (MDMA, Ecstasy), NAT'L HighwAY TRAFFIC SAFETY ADMIN., http://www.nhtsa.gov/people/injury/research/job185drugs/methyl enedioxymethamphetamine.htm (last visited May 11, 2015).

${ }^{435}$ BEAR ET AL., supra note 53, at 547; MCKIM \& HANCOCK, supra note 126, at 235; Shizgal \& Hyman, supra note 123, at 1107. 
tional dopamine into the synapse via the transporter. ${ }^{436}$ Thus, the effects of norepinephrine and dopamine at the synapses are prolonged and intensified. ${ }^{437}$ Because naltrexone, an opioid antagonist, reduces craving, pleasure, and use of amphetamine, it is likely that the endogenous opioid system is responsible for the euphoria created by amphetamine. ${ }^{438}$

If a lawyer uses amphetamine, it stays in her system for seven to thirty hours, producing a longer-lasting high than she can achieve with a single administration of cocaine. ${ }^{439}$ She will experience considerable sympathomimetic symptoms from the norepinephrine that are similar to those caused by cocaine (elevated heart rate, blood pressure, and temperature). ${ }^{440}$ While she may feel more alert, awake, and confident, ${ }^{441}$ she is exposing her brain to damage of the dopamine axons and terminals in the thinking and emotional brains and longlasting dopamine reduction. ${ }^{442}$ Chronic amphetamine use results in deficits of dopamine and serotonin in the brain; elevated blood pressure; and increased risk of stroke, heart attack, hardening of the arteries, and death. ${ }^{443}$

Mephedrone is a stimulant derived from the substance in the khat plant, known as bath salts or plant food, that inhibits the reuptake of dopamine and serotonin and increases the levels of these transmitters in the NAC. ${ }^{444}$ It was sold legally until 2011 and early research results indicate risks of use include compromised serotonin and dopamine systems in the brain, excessive and prolonged sympathomimetic activity, agitation, seizures, and death. ${ }^{445}$

ADHD medications, used to treat attention deficit hyperactivity disorder (“ADHD”), include Adderall (mixed amphetamine salts) and Ritalin (methylphenidate). ${ }^{446}$ Children with ADHD exhibit inattentiveness, impulsivity, and excessive movement. ${ }^{447}$ Between 3 percent and 7 percent of children, and three times more boys than girls, are diagnosed with ADHD. ${ }^{448}$ One theory is that dopamine transporters do not reuptake the right amount of dopamine in brains impacted by ADHD, so there is less dopamine than necessary to produce a clean signal for transmission between neurons. ${ }^{449}$ Reduced dopamine levels result in a compromised reward signal that lacks appropriate timing con-

436 MCKIM \& HANCOCK, supra note 126, at 233; MEYER \& QUENZER, supra note 103, at 364-65; Shizgal \& Hyman, supra note 123, at 1106.

437 BEAR ET AL., supra note 53, at 547.

438 MCKIM \& HANCOCK, supra note 126, at 252.

439 MEYER \& QUENZER, supra note 103, at 364.

${ }^{440} I d$. at $346,365$.

441 Id. at 365 .

442 Id. at 368 .

$443 \mathrm{Id}$. at 369.

444 Id. at 370 .

${ }^{445}$ Id.

446 LINDEN, supra note 86, at 40; MEYER \& QUENZER, supra note 103, at 366.

447 MEYer \& QuenZer, supra note 103, at 366.

448 GiBB, supra note 25, at 164.

449 CARLSON, supra note 208, at 599; GiBB, supra note 25, at 165. 
nection to the stimulus or produces no effect. ${ }^{450}$ Low doses of ADHD stimulants calm over half the children impacted by ADHD. ${ }^{451}$

Ritalin and Adderall have been used as study drugs to increase concentration and reduce fatigue. ${ }^{452}$ Increased wakefulness and a reduced need for sleep are caused by significant synaptic increase in dopamine and norepinephrine. ${ }^{453}$ Up to 25 percent of college students are self-medicating to get an edge on exams or fuel marathon study sessions. ${ }^{454}$ Ritalin is a dopamine agonist that works by blocking dopamine transporters and preventing reuptake, leaving more dopamine in the synaptic gap. ${ }^{455}$ Because Ritalin alleviates ADHD symptoms, scientists believe the disorder is caused by deficiencies in dopaminergic transmission. ${ }^{456}$ Research shows that a moderate dose of Ritalin improves attention and working memory, and increases the responsiveness of neurons in the thinking brain, but a high dose profoundly suppresses neural activity. ${ }^{457}$ Adderall, an amphetamine, causes the release of both dopamine and epinephrine into the synaptic cleft through their transporters, and their lingering impact in the cleft is due to the blocked transporters. ${ }^{458}$

Risks of these medications include sympathomimetic increases in heart rate and blood pressure, as well as abuse potential because administration via snorting or injection can cause euphoria. ${ }^{459}$ Animal research has shown that Ritalin and Adderall can alter brain structure and function that results in greater anxiety, gloomy moods, and cognitive deficits, similar to impairment caused by cocaine (poor impulse control, inability to appreciate consequences, decreased brain volume). ${ }^{460}$

Law and medical students are using Ritalin and Adderall to gain an edge in education systems where students face "steep grading curves and declining job prospects." ${ }^{\text {"461 }}$ Some students procure these drugs with prescriptions and others purchase them on the black market. ${ }^{462}$ Surveys of university students indicate that somewhere between 6.9 percent and 60 percent of students have used prescription stimulants for cognitive enhancement. ${ }^{463}$ Ritalin and Adderall are

450 Horstman, DAY IN THE LiFe, supra note 11, at 91.

451 MEYer \& QuenZER, supra note 103, at 366.

${ }^{452}$ Id. at $142-43$.

$453 \mathrm{Id}$. at 143.

454 Horstman, Brave New Brain, supra note 25, at 23.

455 CARLSON, supra note 208, at 598; GIBB, supra note 25, at 165.

456 CARLSON, supra note 208, at 598-99.

${ }^{457}$ Id. at 599-600.

458 See MeYER \& QuENZER, supra note 103, at 368.

459 Id. at 366.

460 Horstman, Brave New Brain, supra note 25, at 27-28; Meyer \& QuenZer, supra note 103, at 353, 358; Kelline R. Linton, Scholastic Steroids: Is Generation Rx Cognitively Cheating?, 39 PEPP. L. REV. 989, 997 (2012).

${ }^{461}$ Linton, supra note 460, at 1003.

${ }^{462} I d$. at $1002-03$.

${ }^{463}$ Id. at 1002. 
Schedule II drugs because they have a high potential for abuse or dependence. ${ }^{464}$ Side effects of these drugs include dizziness, headaches, and insomnia, and more serious reactions are blurred vision, seizure, stroke, and death. ${ }^{465}$ As with all amphetamines, use of Ritalin and Adderall can cause a downregulation in dopamine and norepinephrine receptors, reducing the normal function of dopamine and norepinephrine in the lawyer brain. ${ }^{466}$ Animal studies show that when they are trained under the influence of amphetamine, they cannot fully remember what they learned once the amphetamine is out of their system. ${ }^{467}$

\section{Opiates}

Opiates are sedatives derived from the opium poppy. They include 1) the natural opiates: opium, morphine, codeine, and thebaine; 2) the semisynthetic opiates: heroin (which converts to morphine in the brain), Dilaudid, and oxycodone; and 3) the synthetic opiates: OxyContin, fentanyl, Demerol, Darvon, Talwin, and methadone. ${ }^{468}$ The active ingredients in opium are morphine, codeine, and thebaine. ${ }^{469}$

Opium was used in ancient Egypt and Greece for medicinal and recreational purposes, and eating or smoking opium was common in Turkey and Iran where alcohol was banned. ${ }^{470}$ In 1680, English doctor Thomas Sydenham introduced laudanum, which was wine laced with opium, saffron, cinnamon, and cloves. ${ }^{471}$ Laudanum was consumed by many English and American women, and it was an ingredient in infant teething and muscle ache products. ${ }^{472}$ German chemist Friedrich Wilhelm Sertürner isolated morphine from opium in 1805, a pharmacology milestone as the first isolation of an active ingredient from a medicinal plant. ${ }^{473}$ Morphine was used to ease pain in wounded soldiers in the Civil War. ${ }^{474}$ The Bayer drug company introduced heroin, a derivative of morphine, in 1898 as a non-addictive pain killer. ${ }^{475}$ Heroin is approximately ten times more potent than morphine. ${ }^{476}$ Opiates were not regulated in the United States until the 1910s. ${ }^{477}$

464 Id. at 1013 .

465 Id. at 1012.

466 MEYER \& QuENZER, supra note 103, at 369.

467 MCKIM \& HANCOCK, supra note 126, at 242.

468 GIBB, supra note 25, at 213-14; LinDEN, supra note 86, at 40-41; MEYER \& QUENZER, supra note 103, at 307-08 fig.11.4.

469 MCKIM \& HANCOCK, supra note 126, at 255.

470 MEYER \& QUENZER, supra note 103, at 306.

${ }^{471} I d$.

$472 \mathrm{Id}$.

473 Linden, supra note 86, at 48; MEYER \& QUENZER, supra note 103, at 307.

${ }^{474}$ LINDEN, supra note 86, at 49.

475 Id.; MEYER \& QUENZER, supra note 103, at 307.

476 MCKIM \& HANCOCK, supra note 126, at 258.

477 MEYER \& QUENZER, supra note 103, at 306. 
Opiates are rapidly bioavailable via smoking, snorting, subcutaneous injection under the skin, and intravenous ("IV") injection. ${ }^{478}$ Opiates produce profound pain relief, sedation, mood changes, mental clouding, nausea, vomiting, and constipation. ${ }^{479}$ Rapid penetration into the brain via IV or inhalation produces euphoria. ${ }^{480}$ In high doses, opiates result in coma and death due to respiratory failure. ${ }^{481}$ Opium has been used throughout history as a poison, which sheds light on how some users die from accidental overdose. ${ }^{482}$ The receptor antagonists naloxone and nalorphine can prevent or reverse the effects of opioids because of their ability to occupy opioid receptor sites, which means they can save the lives of overdose victims, seconds after administration. ${ }^{483}$

The brain's opiate receptors were discovered in the early $1970 \mathrm{~s}^{484}$ and its endogenous opioids, endorphins, were discovered in the mid-1970s. ${ }^{485}$ Activation of opiate receptors inhibits the release of glutamate, GABA, norepinephrine, acetylcholine, and dopamine. ${ }^{486}$ Activation of opioid receptors can also change gene expression in neurons, causing longer-term alterations in neural transmission. ${ }^{487}$

The effects of opiates are more complex than other drugs because opiates produce reward and reinforcement in the brain in two ways: the dopamine system and via opioid receptors. ${ }^{488}$ Opioid receptors are found in the primitive brain - in the brain stem and spinal cord where they modulate pain and impact respiration - which is why opiate overdose can cause respiratory arrest. ${ }^{489}$ Opioid receptors are also found in the thinking brain (cortex) and the emotional brain (hippocampus, amygdala, thalamus, hypothalamus, VTA, and NAC). ${ }^{490}$ Opioid receptors in both the VTA and $\mathrm{NAC}^{491}$ create reward and reinforcement independent of the dopamine system, but opioids also cause release of dopamine from the VTA to the NAC. ${ }^{492}$

$478 I d$. at 308.

479 BEAR ET AL., supra note 53, at 448; CARLSON, supra note 208, at 625; MEYER \& QUENZER, supra note 103, at 308-09.

480 MEYER \& QUENZER, supra note 103, at 308-09.

481 Id. at 305, 308-09.

482 MCKIM \& HANCOCK, supra note 126, at 270.

483 Id. at 261; MEYER \& QUENZER, supra note 103, at 307.

484 MCKIM \& HANCOCK, supra note 126, at 259; RATEY, supra note 54, at 117 . The receptors were discovered by Sol Snyder and Candace Pert. LindEN, supra note 86, at 44.

${ }^{485}$ GiBB, supra note 25, at 214; LindEN, supra note 86, at 44; MCKIM \& HANCOCK, supra note 126, at 259; MEYER \& QUENZER, supra note 103, at 312.

486 MCKIM \& HANCOCK, supra note 126, at 259.

487 Id. at 260.

488 Shizgal \& Hyman, supra note 123, at 1107.

489 Id.

490 MCKIM \& HANCOCK, supra note 126, at 260.

491 Id.

492 CARlson, supra note 208, at 625; MCKim \& HANCOCK, supra note 126, at 261; MeYer \& QUENZER, supra note 103, at 324-25; Shizgal \& Hyman, supra note 123, at 1108. 
If a lawyer used opiates, he would experience analgesia (pain relief), euphoria, respiratory depression, sedation, decreased blood pressure, hypothermia, constipation, urination problems, pupil constriction, suppression of the vomiting and coughing centers, and reduced sex drive. ${ }^{493} \mathrm{He}$ would also experience insomnia because he would spend more time in lighter sleep stages and less time in slow-wave and REM sleep stages. ${ }^{494}$ Opiate use also diminishes both male and female fertility. ${ }^{495}$ Although opiate use causes an initial high, those feelings are replaced with adverse moods. ${ }^{496}$ An infrequent opiate user would experience lethargic performance on tasks, with greater impairment of motor functions than of cognitive ones. ${ }^{497}$ An opiate-dependent lawyer would show little impairment as a result of tolerance for the drug, unless drug administration is interrupted, throwing him into withdrawal. ${ }^{498}$ Withdrawal from opiates is not life-threatening, but is extremely uncomfortable, like a harsh case of the flu lasting about a week. ${ }^{499}$

Endogenous opioids are involved in the reinforcement of natural rewards, such as food and water. ${ }^{500}$ They likely play a role in the reward and reinforcing impact of some addictive drugs, as well as some foods, because naloxone which blocks opiate receptors reduces the reinforcing effects of alcohol. ${ }^{501}$

Opiates are highly reinforcing for two reasons: 1) they activate the dopamine system ${ }^{502}$ and 2) when opiates activate opioid receptors, they also generate a rewarding effect. ${ }^{503}$ This greatly increases the likelihood that opiates will be used again. ${ }^{504}$

\section{Sedatives}

Anxiety disorders are the most common psychiatric problems, and women are twice as likely as men to suffer from anxiety. ${ }^{505}$ If a lawyer has generalized anxiety disorder, she experiences "excessive and relentless worry," and she is irritable, fatigued, and distracted. ${ }^{506}$ Her thinking brain (prefrontal cortex) is suppressed and her emotional brain panic button (amygdala) is hyperactive. ${ }^{507}$

493 MCKIM \& HANCOCK, supra note 126, at 261-62; MEYER \& QUENZER, supra note 103, at 326 tbl.11.2.

494 MCKIM \& HANCOCK, supra note 126, at 262.

495 Id.

496 Id. at 263.

497 Id. at 264

498 Id.

499 Id. at 267.

500 See CARLSON, supra note 208, at 625.

501 Id.

502 Meyer \& QuenZer, supra note 103, at 324-25.

${ }^{503} I d$. at 315,324 .

$504 I d$. at 325 .

505 MCKIM \& HANCOCK, supra note 126, at 162.

${ }^{506} \mathrm{Id}$.

${ }^{507} \mathrm{Id}$. 
Sedatives are tranquilizers (anxiolytics) used to calm anxiety, but they can cause incoordination, drowsiness, and slow reaction times. ${ }^{508}$ They also reduce neuron excitability. ${ }^{509}$ Benzodiazepines are prescribed currently, and barbiturates were used in the past. ${ }^{510}$

Barbiturates and Benzodiazepines (including Valium and Librium) are indirect agonists of GABA receptors. ${ }^{511}$ GABA is the most important transmitter responsible for inhibiting synapse activity. ${ }^{512}$ Without GABA, the neurons in the brain would be firing uncontrollably and the brain would be unstable. ${ }^{513}$

Barbiturates are calming in low doses, but in high doses they impair walking and talking, and result in unconsciousness, depressed respiration, coma, and death. ${ }^{514}$ The risk of lethal overdose is the reason for the shift away from prescribing barbiturates for anxiety, and instead toward prescribing benzodiazepines. ${ }^{515}$

Benzodiazepines are used to treat anxiety and to aid sleep. ${ }^{516}$ They result in sedation, muscle relaxation, anxiety reduction, and mood regulation. ${ }^{517}$ Their addictive potential relates to GABA reduction. ${ }^{518}$ Benzodiazepines reduce GABA in the VTA, allowing glutamate to inspire dopamine production. ${ }^{519}$ The dopamine system from the VTA to the NA is engaged by benzodiazepines, and a single dose given to lab mice changes the neuroplasticity of the glutamate that drives dopamine production. ${ }^{520}$

The disadvantage of benzodiazepines in controlling anxiety is the undesirable concurrent sedation. ${ }^{521}$ High doses of benzodiazepines cause extreme sedation, but are not life-threatening. ${ }^{522}$ Since they engage the dopamine system, benzodiazepines are addictive. ${ }^{523}$

508 MCKIM \& HANCOCK, supra note 126, at 163; MEYER \& QuenZER, supra note 103, at 531.

509 MEYER \& QUENZER, supra note 103, at 531.

510 MCKIM \& HANCOCK, supra note 126, at 163.

511 CARLSON, supra note 208, at 123; MCKIM \& HANCOCK, supra note 126, at 164; MEYER \& QUENZER, supra note 103, at 286.

512 See CARLSON, supra note 208, at 123.

513 Id.; MCKIM \& HANCOCK, supra note 126, at 167.

514 MCKIM \& HANCOCK, supra note 126, at 168-69; see CARLSON, supra note 208, at 123.

515 MCKIM \& HANCOCK, supra note 126, at 169.

516 CARLSON, supra note 208, at 123.

517 MCKIM \& HANCOCK, supra note 126, at 168.

$518 I d$. at 169.

$519 \mathrm{Id}$.

${ }^{520} \mathrm{Id}$.

$521 \mathrm{Id}$. at 168 .

$522 \mathrm{Id}$.

$523 I d$. at 169. 


\section{Hallucinogens}

Hallucinogens, such as lysergic acid diethylamide ("LSD"), phencyclidine ("PCP"), and ketamine, disrupt perception via distortion of senses. ${ }^{524}$ LSD is a powerful psychedelic drug that causes sensory overload by exciting serotonin receptors. ${ }^{525} \mathrm{PCP}$, also known as angel dust, and ketamine are dissociatives that result in sensory deprivation. ${ }^{526} \mathrm{PCP}$ and ketamine are antagonists of glutamate receptors. ${ }^{527}$ The cerebral cortex and hippocampus have many glutamate receptors and blocking them likely contributes to cognitive impairments caused by PCP and ketamine ${ }^{528}$ PCP and ketamine are addictive because they activate the dopamine system. ${ }^{529}$ Ketamine also appears to stimulate opioid receptors. ${ }^{530}$

\section{Foods: Sugar, Fat, and Carbohydrates}

Between 1960 and the present, the average weight of an American adult has increased by approximately twenty-six pounds. ${ }^{531}$ This is because restaurants and food producers serve large portions of foods that thoroughly activate the dopamine system. ${ }^{532}$ The lawyer brain is hardwired to like sugar and fat because they were rare in our ancestral diet and when available, were consumed in large quantities to store for times of famine. ${ }^{533}$

Dopamine and endogenous opioids have a role in the rewarding effects of food. ${ }^{534}$ There are two phases in the reward cycle: hedonic pleasure (liking) and incentive motivation (wanting). ${ }^{535}$ Both dopamine and opioids contribute to enjoyment of and motivation to eat sweet or fatty foods. ${ }^{536}$

Diets that incorporate a lot of sugar or fat generate an increase in dopamine signals. ${ }^{537}$ These foods also cause the release of serotonin. ${ }^{538}$ The more sugar or fat that is consumed, the more dopamine release, resulting in a craving (wanting) for additional sugar or fat. ${ }^{539}$

524 LINDEN, supra note 86 , at 40.

525 BEAR ET AL., supra note 53, at 546; GIBB, supra note 25, at 209-10; MEYER \& QUENZER, supra note 103 , at 432 .

526 GIBB, supra note 25, at 211.

527 MEYER \& QUENZER, supra note 103, at 444.

${ }^{528} \mathrm{Id}$.

529 Id. at 445.

${ }^{530}$ GiBB, supra note 25, at 211; MEYER \& QUENZER, supra note 103, at 445.

531 LINDEN, supra note 86 , at 82-83.

532 Id. at 83 .

${ }^{533} I d$.

534 MeYer \& QuENZER, supra note 103, at 249, 314.

$535 I d$. at 314.

536 Id. at $249,314$.

537 CARTER ET AL., Human Brain, supra note 12, at 113.

538 SWEENEY, supra note 15 , at 198.

539 CARTER ET AL., HuMAN Brain, supra note 12, at 113; Linden, supra note 86, at 83-84; SWEENEY, supra note 15, at 198. 
Sugar, fats, and carbohydrates increase endogenous opioids in rat studies. ${ }^{540}$ Opioid antagonists reduce consumption of these highly palatable foods, while reinstating consumption of standard rat chow. ${ }^{541}$ Administration of additional opioids, such as morphine, increases consumption of chocolate cookies, fat, and carbohydrates. ${ }^{542}$

Rapid and generous pleasure signals are the most rewarding and addictive. ${ }^{543}$ The combination of fat and sugar produces a larger reward signal than either of them independently, making that concoction uber addictive. ${ }^{544}$

A number of pleasurable activities activate the dopamine system and trigger the release of dopamine: playing video games, having sex, gambling, shopping, and exercise. ${ }^{545}$ Consumption of fat, sugar, carbohydrates, and drugs of abuse engage the dopamine system, which was designed to motivate repeated behavior. ${ }^{546}$ If repeated enough, this could lead to an addiction.

\section{THE ADDICTED LAWYER BRAIN}

Even if the lawyer is not worried about the impacts of casual drug use, there is always the potential that recreational drug use could become addiction. The dopamine system is intimately involved in reward-based learning. ${ }^{547}$ The reinforcing effects of dopamine are involved in the addictive properties of drugs. ${ }^{548}$ Drugs that powerfully activate the dopamine system (cocaine, amphetamine, and heroin) carry the greatest risk of addiction, while drugs that weakly activate it (alcohol and cannabis) present a lower risk. ${ }^{549}$ Drugs that do not activate the dopamine system (LSD and SSRI anti-depressants) carry little to no risk of addiction. ${ }^{550}$

Hedonism is the pursuit of pleasure and anhedonia or dysphoria is the inability to feel pleasure. ${ }^{551}$ Early drug use often involves wanting the rush, euphoria, or high. ${ }^{552}$ Transition to addiction occurs when drug use evolves from drug wanting and motivation for the drug reward, to drug needing and how bad the user feels without the drug. ${ }^{553}$

\footnotetext{
540 MeYer \& QueNZER, supra note 103, at 314.

${ }^{541} I d$.

542 Id.

543 LINDEN, supra note 86 , at 84.

${ }^{544} \mathrm{Id}$.

545 DoIDGE, supra note 7, at 309; MEYER \& QUENZER, supra note 103, at 234-35.

546 LINDEN, supra note 86, at 83-84.

547 MCKIM \& HANCOCK, supra note 126, at 116.

$548 I d$. at 119.

549 GIBB, supra note 25, at 192; LINDEN, supra note 86, at 47.

550 GIBB, supra note 25, at 202; LINDEN, supra note 86, at 47.

551 SAPOLSKY, supra note 10, at 272.

552 Id. at 345.

553 CARTer ET Al., Human Brain, supra note 12, at 128; SAPOlSKY, supra note 10, at 345.
} 
Addiction is a form of learning, ${ }^{554}$ and dopamine is responsible for motivating behavior. ${ }^{555}$ When a lawyer needs a drug, the dopamine system is activated. ${ }^{556}$ The dopamine pathway begins in the VTA and the long neurons extend to the NAC where dopamine is released. ${ }^{557}$ The NAC connections provide coordination of motivation, emotional content, and motor responses. ${ }^{558}$ The first release of dopamine in the NAC is in response to the need, and it causes the lawyer to seek the drug. ${ }^{559}$ Information about the location of the drug is recalled from the lawyer's thinking-emotional brain loop where it is stored. ${ }^{560}$ The dealer or friend who provides the drug has incentive salience. ${ }^{561}$ Incentive means the lawyer is attracted to the supplier and salience means the supplier commands the lawyer's attention in the future. ${ }^{562}$ The more the lawyer procures the drug this way, the greater the incentive salience is attached to the drug supplier. ${ }^{563}$ Soon, dopamine release will be prompted by the supplier (stimulus), rather than the drug (reward). ${ }^{564}$ All the rituals associated with the lawyer's drug use will have incentive salience; they are readily perceived, attentiongrabbing, and promote drug wanting. ${ }^{565}$

There is a difference between the lawyer's drug wanting (motivation or craving) and drug liking (euphoria, high, or pleasure). ${ }^{566}$ Drug wanting is mediated by the dopamine system when incentive salience drives the lawyer to seek the drug. ${ }^{567}$ Dopamine release in the NAC evolves a neutral stimulus, such as a drug-supplying friend or drug use location, into a desire stimulus via the establishment of incentive salience. ${ }^{568}$ Researchers have discovered dopamine's role as a reinforcer by blocking its action in the brain. ${ }^{569}$ Blocking dopamine receptors or limiting dopamine release from destroyed axons does not stop an animal from eating a sweet food reward, but it does decrease motivation and attempts to obtain it. ${ }^{570}$ Mice with increased dopamine are more motivated to acquire sucrose, but show normal levels of liking the sweet solution. ${ }^{571}$ Liking seems to

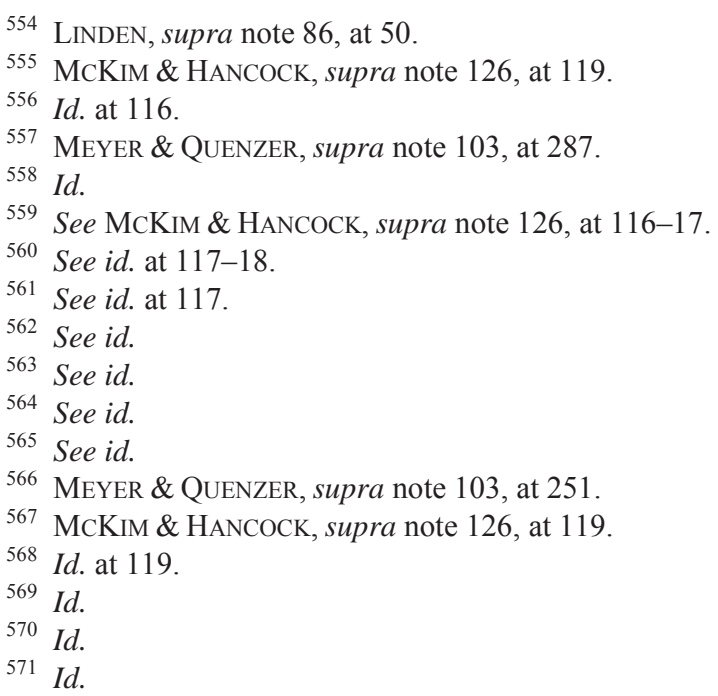


be driven by the presence of endogenous opioids or endocannabinoids ${ }^{572}$ or opiate or cannabinoid drugs, ${ }^{573}$ in small areas of the NAC and ventral pallidum. ${ }^{574}$

Motivation in the complex motivation control system is mediated by dopamine. ${ }^{575}$ Its role is to ensure the lawyer takes actions, again and again, that guarantee her survival. ${ }^{576}$ It was meant to reinforce natural rewards, and these reinforcers have satiation mechanisms that maintain allostasis. ${ }^{577}$ Drugs access the brain in high concentrations soon after dosing, creating intense dopamine surges that appear to have no limits on reinforcing capacity. ${ }^{578}$ Concurrent surges of reinforcing dopamine with pleasure-inducing opioids and cannabinoids (endogenous or artificial) guarantee the lawyer will be motivated to seek and use drugs that cause this activation of the motivation control system. ${ }^{579}$

Stress hormones have a unique relationship with the dopamine system. Stress hormones activate the dopamine system, causing release of dopamine in the NAC, and repeated exposure to stress sensitizes the dopamine system. ${ }^{580}$ Stress hormones also amplify the reinforcing effects of drugs. ${ }^{581}$ Thus, a stressed lawyer who self-medicates with a drug may be more vulnerable to addiction.

The American Psychiatric Association's Diagnostic and Statistical Manual of Mental Disorders ("DSM-5") designates a substance use disorder as "a maladaptive pattern of substance use, over at least a 12-month period, that has led to significant impairment or distress by clinical standards." ${ }^{582}$ Drugs of abuse (nicotine, alcohol, amphetamine, cocaine, morphine, and heroin) activate the dopamine system, causing dopamine release in the NAC. ${ }^{583}$ The dopamine enhances the salience of drug-related stimuli and reinforces the impacts of the drug. ${ }^{584}$ Characteristics of addiction include: tolerance, a reduced drug response after repeated doses; ${ }^{585}$ and dependence, when drug abstinence produces withdrawal symptoms. ${ }^{586}$

${ }^{572} I d$.

573 See MeYer \& QuenZer, supra note 103, at 249.

574 MCKIM \& HANCOCK, supra note 126, at 118; MEYER \& QUENZER, supra note 103, at 249.

575 MCKIM \& HANCOCK, supra note 126, at 119; MEYER \& QuENZER, supra note 103, at $251-52$.

576 MCKIM \& HANCOCK, supra note 126, at 119.

$577 I d$. at 120.

${ }^{578} \mathrm{Id}$.

579 See id.

$580 \mathrm{Id}$.

581 Id.

582 MEYER \& QUENZER, supra note 103, at 233.

583 MCKIM \& HANCOCK, supra note 126, at 125; MEYER \& QUENZER, supra note 103, at 249.

584 MCKIM \& HANCOCK, supra note 126, at 125.

585 Id. at 40; MEYER \& QUENZER, supra note 103, at 32-33.

586 MCKIM \& HANCOCK, supra note 126, at 44; MEYER \& QUENZER, supra note 103, at 242. 
Chronic overstimulation of the dopamine system creates an adjustment or down-regulation of the system. ${ }^{587}$ The result is a decrease in dopamine release in the NAC when drugs of abuse are stopped. ${ }^{588}$ Withdrawal from alcohol, nicotine, amphetamine, cocaine, and heroin decreases the activity of the dopamine system and the release of dopamine in the NAC. ${ }^{589}$ Decreased activation of the dopamine system may cause a lack of interest in natural rewards such as social events or recreational activities. ${ }^{590}$ Chronic drug use may impair thinking brain functions such as decision-making, attention, and impulse control. ${ }^{591}$

Neuroplasticity, neurogenesis, and epigenetics ensure there is always a path to strengthen the lawyer brain.

\section{HEALING THE LAWYER BRAIN}

NQ reveals that lawyers have a great deal of control over cognitive power, and that legal cultures can inspire or compromise the cognitive capacities of constituents. The lawyer brain is continuously evolving with each experience, thought, and feeling. Choices lawyers make can imperil or amplify cognitive function because the lawyer brain can grow new brain cells in the hippocampus (neurogenesis); activate and deactivate genes (epigenetics); and make new connections in its vast networks (neuroplasticity).

Results from a 2011 meta-analysis (1,603 articles) of research on the relationship between exercise and cognition show that exercise can both prevent cognitive deterioration and heal cognitive damage. ${ }^{593}$ Exercise improved minor memory loss as well as the effects of Alzheimer's Disease. ${ }^{594}$ The key advantage was attributed to improved neurogenesis and neuroplasticity, facilitated by neurotrophins. ${ }^{595} \mathrm{~A}$ critical finding was that exercisers developed "significantly larger hippocampal volumes" and more robust synaptic connections. ${ }^{596}$

A study of 1.2 million Swedish boys who entered the military between 1950 and 1976 measured cardiovascular fitness and cognitive abilities. ${ }^{597}$ Car-

587 BEAR ET AL., supra note 53, at 569 box 16.5; GiBB, supra note 25, at 192.

588 BEAR ET AL., supra note 53, at 569 box 16.5; SwEENEY, supra note 15, at 202.

589 CARLSON, supra note 208, at 624.

${ }^{590}$ MCKIM \& HANCOCK, supra note 126, at 126.

$591 \mathrm{Id}$.

592 Carter et Al., Human Brain, supra note 12, at 193; Horstman, Brave New Brain, supra note 25, at 8; SwEENEY, supra note 15, at 17; Bargmann \& Gilliam, supra note 68; see DOIDGE, supra note 7, at 45-47.

593 RATEY \& MANNING, supra note 67, at 105-06. Sedentary lifestyle has been associated with a decline in cognitive skills and the following diseases: heart failure, heart attack, coronary artery disease, hypertension, stroke, type 2 diabetes, asthma, obstructive pulmonary disease, arthritis, immune dysfunction, and cancers of the breast, colon, prostate, and pancreas. Id. at 104 .

594 Id. at 106.

595 Id. at 107.

${ }^{596} \mathrm{Id}$.

597 Id. at 109. 
dio fitness was a better predictor of cognitive ability and IQ than familial history, and those with higher fitness scores had better education, greater life satisfaction, and higher socioeconomic standing as adults. ${ }^{598}$ Exercise has improved standardized test scores for students at schools in Illinois ${ }^{599}$ and California. ${ }^{600}$

\section{A. Exercise and Brain Health}

Nike's ubiquitous meme "Just Do It" ${ }^{\prime \prime 01}$ is the right advice for the lawyer who wishes to enhance or heal her brain. "[E]xercise is the single most powerful tool you have to optimize your brain function." which increases the lawyer heart rate for an extended period ${ }^{603}$ - benefits the lawyer brain in three ways:

(1) it increases blood and oxygen flow;

(2) it elevates and balances important neurotransmitters; and

(3) it stimulates the release of neurotrophins. ${ }^{604}$

When a lawyer raises her heart rate with aerobic exercise, her blood vessels produce nitric oxide, which allows blood to flow deeper into body and brain tissues. $^{605}$ The lawyer brain requires 25 percent of the body's blood flow, 20 percent of its oxygen, and 25 percent of its calories. ${ }^{606}$ Greater blood flow maximizes the distribution of oxygen and nutrient resources to the brain, and improves elimination of waste. ${ }^{607}$ One study put a group of volunteer participants on a three-month exercise regimen, and brain scans showed a 30 percent increase in their hippocampal capillaries. ${ }^{608}$ Exercise increases blood volume in the hippocampus, keeping it hearty and well-functioning. ${ }^{609}$

Normal brain function requires complex synaptic transmission with the aid of a delicate concoction of neurotransmitters. No activity beats aerobic exercise for taming transmitters and creating neurochemical harmony in the brain. Signaling in the brain is largely the responsibility of glutamate (excites and activates neurons) and GABA (calms and inhibits neurons). ${ }^{610}$ Regulating brain processes, such as signaling, is the duty of serotonin, norepinephrine, and do-

598 Id.

599 RATEY, supra note 54, at 9-12.

600 Id. at 21-22.

601 Just Do It, NiKE, http://www.nike.com/us/en_us/c/justdoit (last visited May 15, 2015).

602 RATEY, supra note 54, at 245.

603 AMEN, supra note 22, at 110.

604 Id.; Horstman, BRAVE New BRAIN, supra note 25, at 29; MedinA, supra note 12, at 22; PERLMUTTER \& Villoldo, supra note 25, at 87-97; RATEY, supra note 54, at 38.

605 MEDINA, supra note 12, at 21.

606 AMEN, supra note 22, at 17.

607 MEDINA, supra note 12, at 21-22.

608 RATEY, supra note 54, at 246.

609 CARTER ET AL., HuMAN BRAIN, supra note 12, at 65; MEDINA, supra note 12, at 22; Amaral \& Strick, supra note 186 , at 349.

610 BROAD, supra note 54, at 99; RATEY, supra note 54, at 37. 
pamine. ${ }^{611}$ Most drugs aimed at improving mental health issues target these regulating neurotransmitters. ${ }^{612}$ Serotonin affects mood, emotion, appetite, and sleep. ${ }^{613}$ Norepinephrine governs attention, arousal, heartbeat, and blood pressure. ${ }^{614}$ Dopamine manages motivation and reinforcement. ${ }^{615}$ Aerobic exercise has the unique power to both elevate and balance these key regulating transmitters. ${ }^{616}$

While neurotransmitters ensure communication between neurons, a group of proteins called neurotrophins are responsible for cultivating brain cells. ${ }^{617}$ The neurotrophins are brain-derived neurotropic factor ("BDNF"), ${ }^{618}$ insulinlike growth factor ("IGF-1"), vascular endothelial growth factor ("VEGF"), and fibroblast growth factor ("FGF-2"). ${ }^{619}$ These neurotrophins are all elevated by aerobic exercise. ${ }^{620}$

BDNF was discovered in 1990 to nourish brain cells in the hippocampus like a fertilizer, ${ }^{621}$ making it especially important to learning and memory. ${ }^{622}$ BDNF is essential to neurogenesis because it helps create new neurons, and it is crucial to neuroplasticity because it facilitates synapse formation. ${ }^{623}$ Vital also to epigenetics, the gene that boosts BDNF production is switched on by exercise and intellectual stimulation. ${ }^{624}$ Nutrition plays a role in the acquisition of BDNF. Excess sugar decreases BDNF, while food rich in folate, Vitamin B12, curcumin (the active ingredient in turmeric), and omega-3 fats increase BDNF. ${ }^{625}$

BDNF causes the growth of new dendrites, the neuron branches that receive information from the presynaptic axon. ${ }^{626}$ It binds to the receptors on the

611 RATEY, supra note 54, at 37.

${ }^{612}$ Id. at $37-38$.

${ }^{613}$ Carter et Al., Human Brain, supra note 12, at 231; CARTer, Mapping the Mind, supra note 20, at 28; HoRSTMAN, DAY IN THE LIFE, supra note 11, at 8, 34; RATEY, supra note 54, at 37; SWEENEY, supra note 15, at 15, 221.

614 SWEENEY, supra note 15, at 15, 221.

${ }^{615}$ CARTER, MAPPING THE Mind, supra note 20, at 29.

616 MEDINA, supra note 12, at 16-17; RATEY, supra note 54, at 38.

617 RATEY, supra note 54, at 38.

${ }^{618} I d$.

${ }^{619} I d$. at 51

${ }^{620}$ DOIDGE, supra note 7, at 255; RATEY, supra note 54, at 50-53.

${ }^{621}$ AMEN, supra note 22, at 110; MEDINA, supra note 12, at 22; RATEY, supra note 54, at $38-39$.

622 RATEY, supra note 54, at 39.

${ }^{623}$ AAMOdT \& WANG, supra note 193, at 89; DeEpak CHOPRA \& Rudolph E. TANZI, Super Brain: Unleashing the Explosive Power of Your Mind to Maximize Health, Happiness, \& Spiritual Well-Being 35 (2012); Doidge, supra note 7, at 80; Perlmutter \& VILLOLDO, supra note 25 , at 87.

${ }^{624}$ Medina, supra note 12, at 22; Perlmutter \& Villoldo, supra note 25, at 88-92.

${ }^{625}$ Perlmutter \& Villoldo, supra note 25, at 93; RATEY \& MANNING, supra note 67, at 93.

${ }^{626}$ RATEY, supra note 54, at 40. 
postsynaptic dendrites, improving the signal strength of the information. ${ }^{627}$ Inside the neuron, BDNF activates the genes that produce serotonin and increase BDNF production. ${ }^{62}$ BDNF behaves like a brain cell fertilizer because it grows, strengthens, and protects neurons. ${ }^{629}$

Scientists have learned about the importance of BDNF through rodent studies because rodents naturally enjoy activity. ${ }^{630}$ Mice who ran on a wheel increased their hippocampal BDNF over sedentary control-group mice, and the more they ran, the higher the BDNF increases. ${ }^{631}$ BDNF increases the rate of learning. ${ }^{632}$ Mice are not fond of water, so one experiment tested their ability to remember a platform escape route from their rodent swimming pool. ${ }^{633}$ Wheelrunners remembered the escape route and swam for it immediately. ${ }^{634}$ Couch potato mice struggled to figure out how to exit the pool, and when dissected, wheel-runners had twice the new hippocampal neurons as couch potatoes. ${ }^{635}$ In 2007, researchers showed that humans learned vocabulary words 20 percent faster after exercise than before exercise, and that the learning rate correlated directly with levels of BDNF. ${ }^{636}$

The three other neurotrophins (IGF-1, VEGF, and FGF-2) are elevated by exercise and work with BDNF to build and maintain brain cell circuitry. ${ }^{637}$ During exercise, IGF-1 is released by muscles when they sense a need for glucose ${ }^{638}$ Glucose is the sole source of energy for the brain and the major source for muscles, and IGF-1 works with insulin to deliver glucose to the cells. ${ }^{639}$ BDNF and IGF-1 collaborate to empower learning because during exercise, BDNF increases the uptake of IGF-1 ${ }^{640}$ IGF-1 then activates glutamate and serotonin release, and encourages BDNF receptor growth, enhancing the synaptic connection necessary for memory consolidation. ${ }^{641}$ Glucose empowers learning, ${ }^{642}$ new blood vessels are needed to deliver glucose to the cells, and VEGF builds more capillaries in both the body and brain when exercise signals

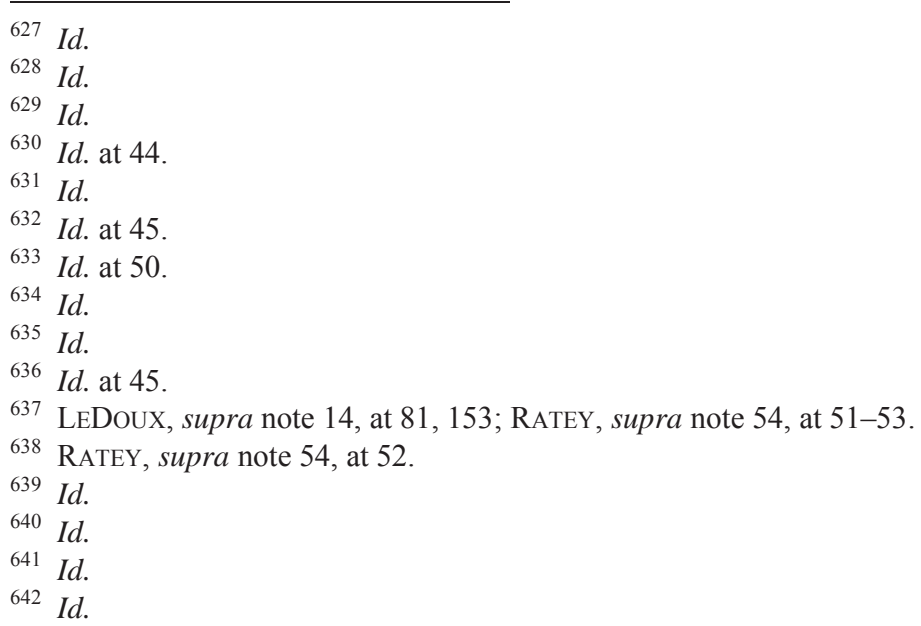


low oxygen. ${ }^{643}$ FGF-2 aids cell growth and facilitates long-term potentiation (“LTP”). ${ }^{644}$

As lawyers age, the natural production of the neurotrophins is reduced. ${ }^{645}$ This depresses the rate of neurogenesis. ${ }^{646}$ Aerobic exercise increases BDNF, IGF-1, VEGF, and FGF-2 in the lawyer brain, so neural degeneration can be curtailed or delayed. ${ }^{647}$

A busy lawyer who is now convinced that she should either start or increase aerobic exercise to empower her brain might wonder how much exercise is necessary. Thirty minutes of exercise two or three times per week can improve cognitive function. ${ }^{648}$ Daily exercise elevates BDNF more than on alternate days. ${ }^{649}$ The bottom line is the more fit the body, the greater the cognitive benefit. ${ }^{650}$ Our genes are coded for consistent activity, from a time when we had to worry about locating and acquiring food. ${ }^{651}$ To fully engage the endurance metabolism, lawyers should do a low or moderate-intensity activity every day and a high-intensity activity a couple of times per week. ${ }^{652}$ Interval training increases BDNF and norepinephrine production. ${ }^{653}$ Should a lawyer get sick or injured and have to suspend exercise for a short period, the hippocampus has a "molecular memory" for producing BDNF, and even if exercise is paused for two weeks, it takes just two days of exercise to return the hippocampus to BDNF fighting form. ${ }^{654}$

A lawyer who enjoys strength training might wonder about its benefits. When weight lifters train, they engage in a process known as hormesis. ${ }^{655}$ Hormesis is a response to a low dose of a stressor, such as exercise, that damages muscles due to overuse and then repairs them at bigger and better strength. ${ }^{656}$ Hormesis develops resilience in the body and brain. ${ }^{657}$ One study showed that older adult weight lifters increased levels of IGF-1, VEGF, and FGF-2 to levels of a thirty-year-old, rather than their average age of sixty-five years. ${ }^{658}$ Yoga practitioners are able to increase their GABA levels, even when

643 Id.

644 LEDOUX, supra note 14, at 153; RATEY, supra note 54, at 52-53.

645 AMEN, supra note 22, at 161-62; RATEY, supra note 54, at 52-53.

646 RATEY, supra note 54, at 53.

647 Id. at 51-53.

648 Id. at 55.

649 Id. at 261.

650 Id. at 245-51.

651 Id. at 248.

652 Id. at $248-50$.

653 Id. at 257.

654 Id. at 261-62.

655 RATEY \& MANNING, supra note 67, at 103.

656 Id.

657 Id.

658 RATEY, supra note 54, at 258. 
they are new to the practice, although more experienced yogis show the greatest GABA increases. ${ }^{659}$

Complex movement, that which requires skills greater than mindless treadmill running or stationary bike pedaling, provides different beneficial effects in the brain. ${ }^{660}$ Rats trained on an obstacle course had a 35 percent increase in BDNF in the cerebellum (largely responsible for movement), where wheel-running rats had none. ${ }^{661}$ Beneficial practices such as yoga, dance, Pilates, karate, and CrossFit can build robust brain resources that can be coopted for cognition. ${ }^{62}$

\section{B. Exercise and Stress, Anxiety, and Depression}

"Evolution has made provisions for our happiness, but to take advantage of them you've got to move.",663

The hippocampus is "obsessed with the stress," tive to the stress hormone cortisol. ${ }^{665}$ A small amount of cortisol helps memory formation, but too much suppresses memories. ${ }^{666}$ The fight-or-flight SNS stress response begins when cortisol and norepinephrine boost glutamate production, which speeds up the flow of information in the hippocampus. ${ }^{667}$ Cortisol activates the genes that produce neurotrophins, which generate additional dendrites and receptors, and forge more powerful synapses. ${ }^{668}$ These new brain resources vigorously secure the stress-based survival memory, while buffering the neurons in that circuit from other memories. ${ }^{699}$ Thus, memories that are not related to the stressor are obstructed during the fight-or-flight response. ${ }^{670}$ This explains why it is hard to learn new material, and also why studies show it is difficult to retrieve existing memories, when the lawyer brain is exposed to chronic stress. ${ }^{671}$ The neurons in the hippocampus have boosted glutamate and diverted neurotrophins to shut out the stimuli that are not related to survival. ${ }^{672}$ When subjected to stress hormones, the hippocampus shrinks and the extent of

659 BROAD, supra note 54; RATEY, supra note 54, at 259.

660 RATEY, supra note 54, at 55-56; RATEY \& MANNING, supra note 67, at 119-22.

661 RATEY, supra note 54, at 55.

${ }^{662}$ Id. at 56; RATEY \& MANNING, supra note 67, at 120-22.

${ }^{663}$ RATEY \& MANNING, supra note 67, at 119.

664 RATEY, supra note 54, at 68.

${ }^{665} I d$. at 66-67.

666 Id. at 67.

${ }^{667} I d$.

${ }^{668} I d$.

${ }^{669} I d$.

670 Id. at 68.

${ }^{671} I d$.

${ }^{672} I d$. 
hippocampal reduction and memory loss is directly proportional to the rise in cortisol. ${ }^{673}$

BDNF, the premier neurotrophin, can protect against stress hormones as long as there are sufficient amounts in the brain. ${ }^{674}$ Exercise increases all the neurotrophins, helping to inoculate the brain against stress. ${ }^{675}$ Exercise raises the fight-or-flight response threshold, subdues cortisol release, and increases and balances the regulatory transmitters serotonin, norepinephrine, and dopamine. ${ }^{676}$

Exercise is helpful in both treating and preventing anxiety and depression. ${ }^{677}$ Scientists believe the reason it is ameliorative and preventative is because it elevates and rebalances levels of serotonin, norepinephrine, and dopamine in the brain. ${ }^{678}$ In 2010, the American Psychiatric Association listed exercise as a proven depression treatment. ${ }^{679}$

Stress and depression can cause a drop in neurotrophin levels and a corresponding reduction in neurogenesis. ${ }^{680}$ Exercise increases BDNF, IGF-1, VEGF, and FGF-2, so it is a powerful prescription for relieving stress and improving depression. ${ }^{681}$

Getting treatment for anxiety and depression can reduce stress and reverse hippocampal damage. ${ }^{682}$ Research shows that exercise significantly mitigates symptoms of anxiety disorders. ${ }^{63}$ Exercise increases GABA, the calming transmitter that is a primary target for anti-anxiety medications. ${ }^{684}$ It also elevates serotonin, which helps the prefrontal cortex calm the panicky amygdala. ${ }^{65}$

When the lawyer increases her respiration and heart rates with exercise, she is training her brain to understand that the symptoms of fight-or-flight activation can be beneficial. ${ }^{686}$ Several large studies have concluded that exercisers are less anxious and depressed, less stressed and more socially outgoing. ${ }^{687}$ In addition to exercise, lawyers could add a restorative practice like yoga, mind-

\footnotetext{
673 Id. at 76.

674 MEDINA, supra note 12, at 179.

675 RATEY, supra note 54, at 72-73.

${ }^{676}$ Id. at 78-79.

677 MEDINA, supra note 12, at 16-17; RATEY, supra note 54, at 37-38.

678 MEDINA, supra note 12, at 16-17; RATEY, supra note 54, at 37-38.

679 RATEY \& MANNING, supra note 67, at 110.

${ }^{680}$ RATEY, supra note 54, at 53.

$681 \mathrm{Id}$.

682 See id.

683 Id. at 92.

${ }^{684} \mathrm{Id}$.

${ }^{685} \mathrm{Id}$. at 107.

${ }^{686} \mathrm{Id}$.

${ }^{687} \mathrm{Id}$. at 119.
} 
fulness, meditation, or gratitude, shown to empower the rest-and-digest PNS and reduce the impacts of stress. ${ }^{688}$

People with depression suffer from low levels of BDNF. ${ }^{689}$ Antidepressant medications increase the rate of neurogenesis. ${ }^{690}$ Exercise increases BDNF at least as much, and sometimes more, than antidepressants. ${ }^{691}$ Research shows that exercise augments antidepressants in some patients, ${ }^{692}$ and for others it is equally or more effective compared to the medication. ${ }^{693}$ Perhaps the most significant finding is that the more the patient exercises, the greater the improvement in mood. ${ }^{694}$ This may be due to the power of exercise to balance neurotransmitters and increase neurotrophins, the building blocks of brain cells. ${ }^{695}$

\section{Exercise and Substance Use}

All the things a lawyer could become addicted to-caffeine, nicotine, alcohol, drugs of abuse, or food-augment dopamine levels in the NAC. ${ }^{696}$ While having sex increases dopamine levels from 50 percent to 100 percent, cocaine inflates the dopamine rate a mind-boggling 300 percent to 800 percent above normal levels. ${ }^{697}$ The powerful incentive salience of drugs tricks the user brain, via the reinforcing capacity of dopamine, into thinking that this form of reward seeking is a matter of life and death. ${ }^{698}$ Drugs activate the dopamine system in unnatural ways. ${ }^{699}$

Exercise can change brain chemistry and rewire connections harmed by drug use or addiction. ${ }^{700}$ Damaged brain cells can grow back. ${ }^{701}$ Research, demonstrating the hope that neurogenesis can inspire, suggested that chickadees which learn new songs every spring sprout a significant number of new brain cells in the hippocampus in the process. ${ }^{702}$ Simply providing a running

688 See Debra S. Austin, Killing Them Softly: Neuroscience Reveals How Brain Cells Die From Law School Stress \& How Neural Self-Hacking Can Optimize Cognitive Performance, 59 LOY. L. REV. 791, 837-47 (2013).

${ }^{689}$ RATEY, supra note 54, at 131.

${ }^{690}$ Hyman \& Cohen, supra note 176, at 1413.

691 RATEY, supra note 54, at 131.

${ }^{692} I d$. at $125-26$.

${ }^{693}$ Id. at $122-24$.

694 Id. at 124.

${ }^{695} I d$. at 132.

696 Id. at 170 .

697 Id.

${ }^{698} I d$. at 171 .

${ }^{699} I d$.

${ }^{700}$ Id. at $180-81$.

${ }^{701} \mathrm{Id}$. at 48.

${ }^{702} \mathrm{Id}$. at 49. 
wheel for a rodent results in profound cell birth. ${ }^{703}$ Lawyers can grow several thousand new brain cells in the hippocampus every day. ${ }^{704}$

For addicts, exercise can blunt withdrawal symptoms by calming the amygdala and increasing dopamine production. ${ }^{705}$ A 2004 study showed that a mere ten minutes of exercise could reduce cravings in alcoholics. ${ }^{706}$ Exercise can improve self-regulation. ${ }^{707}$ Students on a two-month exercise program were given psychological tests every two weeks and they recorded their daily habits in journals. ${ }^{708}$ Tests showed they improved their self-control, smoked less, drank less caffeine and alcohol, ate a healthier diet, lost their tempers less often, and increased their gym visits. ${ }^{709}$

Research on the phenomenon of the runner's high has been focusing on endocannabinoids such as anandamide and 2-arachidonoylglycerol ("2AG"). ${ }^{710}$ Both of these endocannabinoids are produced in the body and brain during exercise. ${ }^{711}$ When endocannabinoid receptors are strongly activated, the result is a feeling of euphoria, much like that produced from drug use. ${ }^{712}$ Endocannabinoid receptors are activated by cannabis, exercise, and chocolate. ${ }^{713}$

Engaging the lawyer endurance metabolism by doing a combination of low to moderate intensity activity every day and a high-intensity activity two to three times per week, maximizes cognitive and physical benefit. ${ }^{714}$ Pushing exercise limits, even for short periods of time, increases transmitters, endorphins, and endocannabinoids. ${ }^{715}$ When fit male college students ran on treadmills or spun on stationary bikes for fifty minutes, at 70 percent to 80 percent of their maximum heart rate, they increased the endocannabinoid anandamide levels in their blood by nearly 100 percent. ${ }^{716}$ Interval training is a good way to work on this, and small intensity-level increases elevate BDNF and norepinephrine levels. ${ }^{717}$ One study showed that interval training improved learning when treadmill runners incorporated two three-minute sprints over a forty-minute run. ${ }^{718}$

703 Id.

704 CHOPRA \& TANZI, supra note 623, at 34.

705 RATEY, supra note 54, at 179, 182.

${ }^{706} \mathrm{Id}$. at 177 .

707 Id. at 188

${ }^{708} \mathrm{Id}$.

709 Id.

${ }^{710}$ Id. at $182-83$.

$711 \mathrm{Id}$. at 183.

$712 \mathrm{Id}$.

713 Id.

${ }^{714} I d$. at 248.

715 Id. at 256-57.

$716 \mathrm{Id}$. at 183 .

$717 \mathrm{Id}$. at 257.

${ }^{718}$ Id. 
Exercise elevates dopamine levels as well as endorphins. ${ }^{719}$ This improves attention and motivation, and it is reinforcing for any activity that raises the lawyer heart rate, such as running, swimming, cycling, rowing, or CrossFit. ${ }^{720}$ It also releases endocannabinoids in the lawyer brain, making him feel better during and after exercise. ${ }^{721}$

\section{Exercise and Culture}

Neuroendocrinologist Bruce S. McEwen and researcher Linn Getz describe individuals by their tolerance for environmental challenges as dandelions who can thrive anywhere, and orchids who are much more vulnerable. ${ }^{722}$ Armed with NQ, lawyers can improve resilience and build brain capacity, moving closer to the dandelion end of the scale. ${ }^{723}$

An environment that combines learning, exercise, and social contact causes neurons to propagate new dendrites, form more synaptic connections, and improve signaling because the axons have thicker myelin coating. ${ }^{724}$ The lawyer brain can grow several thousand hippocampal brain cells each day, and this process is hastened by exercise, intellectual stimulation, and social connectedness. ${ }^{725}$ Cultures in which law students are educated and lawyers are at work should engender these values. Law schools, law firms, and court systems should facilitate workout groups rather than happy hours.

Now that we know dopamine is responsible for reward reinforcement ${ }^{726}$ and endogenous opioids and/or cannabinoids are responsible for experiencing pleasure, ${ }^{727}$ exercise is the activity lawyers should all be engaging in to:

- build brain resources,

- extinguish the impacts of stress,

- protect against anxiety and depression,

- prevent cognitive decline, and

- replace substance use.

Exercise should be elevated from a "Just Do It"728 position to a "Just Do It Again" imperative, because dopamine is the "Do-It-Again" neurotransmitter. ${ }^{729}$

\footnotetext{
719 Id. at 121 .

${ }^{720} I d$.

721 Id. at 257.

722 RATEY \& MANNING, supra note 67, at 238.

${ }^{723} I d$. at 239

724 RATEY, supra note 54, at 47.

725 CHOPRA \& TANZI, supra note 623, at 34-35.

726 MCKIM \& HANCOCK, supra note 126, at 119; MEYER \& QuENZER, supra note 103, at 251-52.

727 MCKIM \& HANCOCK, supra note 126, at 119.

728 See supra note 601 and accompanying text.

${ }^{729}$ MCKIM \& HANCOCK, supra note 126, at 119.
} 


\section{CONCLUSION}

Starting in law school, the legal profession's continuous stress on the lawyer brain can lead law students, lawyers, law professors, and judges to depression, alcoholism, and drug abuse. This stress impairs the cognitive function of the lawyer brain. However, if law schools, law firms, and court systems support healthier lifestyles to improve cognitive wellness, such as exercise and diet, it will have a positive impact on the culture of the legal profession. 